\title{
Climate Change Adaptation Practices by Ruminant Livestock Producer of in Hintalo Wajerat District Tigray Regional State, Northern Ethiopia
}

\author{
Guo Ruo*1, Brhane Weldegebrial ${ }^{2}$, Genet Yohannes ${ }^{3}$ and Gebremedhin Yohannes ${ }^{4}$ \\ ${ }^{1}$ College of Environmental Science and Engineering, Tongjji University, China \\ ${ }^{2}$ College of Environmental Science and Engineering, University of Tongji, China \\ ${ }^{3}$ College of Agriculture and Natural Resources, Gambella University, Ethiopia \\ ${ }^{4}$ College of Veterinary Medicine, Hawassa University, Ethiopia
}

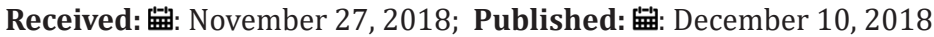

*Corresponding author: Guo Ruo, College of Environmental Science and Engineering, Tongjji University, China

\begin{abstract}
Global warming has been termed 'the greatest market failure the world has ever seen' The earth's climate has warmed on average by about $0.7^{\circ} \mathrm{C}$ over the past 100 years with decades of the 1990s and 2000s being the warmest in the instrumental record .This study a hundred and fifty six farmers' households were interviewed or conducted in January and February 2018 and examined by used descriptive statistical analysis on the climate perception of livestock producer, adaptation practices, effect of climate change on livestock production and barrier to adapt climate change that responded by the local farmers in Hintalo wajerat district of Tire regional state of northern Ethiopia based on different agro ecology. Results showed that Most of the respondents 150 (96.15\%) perceived that, climate change is indeed occurring and 6(3.85) respondents also none perceived whether climate is changed or not. About $122(78.2 . \%)$ of respondents also perceived that increases in temperature. While $110(70.5 \%)$ perceived that decreased in precipitation over the fifteen years. Most of the respondents perceived that, climate change was affected on livestock production and animal feed (forage) production.
\end{abstract}

The major adaptation strategies based on three agro ecological setting identified by the livestock farmers that included, Health care 138 (88.46\%), clean of shade $128(82.05 \%)$, provision of shade 120 (76.92\%), Marketing during shock 97(62.18 \%), Shade for day and dry season $76(48.71 \%)$, used Feeding \& watering trough and cross bred 71(45.51\%) respectively. Other results of descriptive analysis, farmers responded on the different barriers of climate change adaptation practices. Among the barriers such as lack of finance, lack of awareness on climate change adaptation strategies, lack of water and lack of lands. The benefits of climate adaptation practices on livestock that perceived by the farmers' like, increase animal production and productivity, decrease animal pest and disease and other related benefits of climate adaptation practices on livestock. Increased access to agricultural support services, which improves the availability and the quality of relevant climate information will further enhance awareness of climate change within of the rural community and result in better management of climate-induced risks in these vulnerable livestock production systems.

Keywords: HH Perception; Climate Change; Adaptation Strategy; Livestock Productivity

Abbreviations: NMSA: National Meteorological Survey Agency; FGD: Focus Group Discussion; KII: Key Informants Interview; PPS: Probability Proportional Size

\section{Introduction}

Global warming has been termed 'the greatest market failure the world has ever seen' [1]. The earth's climate has warmed on average by about $0.7^{\circ} \mathrm{C}$ over the past 100 years with decades of the $1990 \mathrm{~s}$ and 2000s being the warmest in the instrumental record [2] Agriculture in Africa is more negatively affected by climate change [3]. According to study by Abate et al., (2009), Africa is generally a continent most vulnerable to climate change than other continent due to lack of adaptation capacity. Thornton et al. [4], forecasted that climate change was to bring about shortage of water which could reduce livestock feed and pasture yield. Ethiopia is one of Africa country has a diversified climate ranging from semi-arid desert type in the lowlands to humid and warm (temperate) type 
(NMSA,2001). The size and diversity of major agro-ecological zones is suitable for the support of large numbers and classes of livestock [5]. However, the country has more suffered by extreme climatic change and variability $[6,7]$.

Climate related hazards in Ethiopia include drought, floods, heavy rains, strong winds, frost, heat waves (high temperatures) and lightning than other Africa countries [6]. Tigray is also one of the Regional States in Ethiopia that is frequently affected by drought and other related hazards because it has both arid and semi-arid nature [8]. Consequently, the impacts of climate change and variability remain a serious challenge. According to FDRE 2011 [9] study, by 2020 in Ethiopia, the yields from agriculture could fall by $50 \%$ because of the adverse effects of climate change like rise in temperature, drought, flood, erratic rainfall and others. Climate change has been recognized by different researchers as having potentially severe impacts on livelihood and development [10]. Being a developing country, Ethiopia's agriculture contributes about $42-45 \%$ to its gross domestic product, employs more than $80 \%$ of the population and generates more than $85 \%$ of foreign exchange earnings $[3,11,12]$. Livestock systems in developing countries are characterized by rapid change, driven by factors such as population growth, increases in the demand for livestock products as incomes rise, and urbanization $[13,4]$.

Livestock currently contribute about 30 percent of agricultural gross domestic product in developing countries, with a projected increase to about 40 percent by $2030 \mathrm{FAO}[14,15]$ and is becoming the fastest-growing sub-sector of agriculture $[13,16]$. Livestock are an important component of nearly all farming systems in Ethiopia and provide draught power, milk, meat, manure, hides, skins and other products [5]. Currently, the population of livestock found in Ethiopia is estimated to be 53.4 million cattle, 25.5 million sheep and 22.78 million goats [17]. However, Climate change is affecting the dynamics of livestock sector $[18,19]$. Studies had reported that there are correlations between rainfall variability and livestock population dynamics [20-22]. Among the livestock species, sheep and goats are more vulnerable to climate change due to their heavily reliance on climate sensitive resources and immobility during flood [23], and may not adapt to extreme climate change phenomena such as shortage of fodder, floods and droughts [24,25]. According to AL-Haidary et al. [26-28], study climate changes had the thermal, nutritional, water related stresses, restlessness and affect livestock productivity.

Increased incidence of disease and parasitic infection, decreasing trend of feed and fodder resources, low productive and reproductive performance are also some of the negative effects of climate change [29,30]. According to Deressa et al. [8,31], adaptation remains one of the policy options to address climatic challenges prevailed on all ecosystem especially on the livestock sector such as on cattle, sheep and goats. This has great relevance for developing countries seeking to maintain food security if it is focused to go together with the long-term policy priority among poor farmers [32]. Obviously, farmers with the low capacity are the most vulnerable to the negative impacts of climate variability and change. Within the spectrum of livestock versus adaptation methods to climatic change, has been identified by many researchers [29,30]. Despite significant progress, many questions regarding the prospects for livestock have yet to be recognized [33,34]. Some studies Dick; Tologbonse indicates that, different adaptation methods to climate change are applied by livestock farmers at different agro-ecological zones. Despite the importance of livestock production for the economy of Ethiopia especially for Tigray region very little or not enough information or study exists on climate change and its effect on livestock production.

Then this study was intended to fill the gap in the literature by examining the impact of climate change on livestock production, identified the determinants of adaptation method used by farmers located at each agro-ecological zone, analyzed famers' perception on climate change, types of adaptation practices by ruminant livestock producer farmers in the study area of South Eastern Tigray Zones, Northern Ethiopia. Therefore, the objective of this study is to assess the Climate Change Adaptation Practices by Ruminant Livestock Producer in Hintalo Wajerat District, Tigray Regional state, Northern Ethiopia.

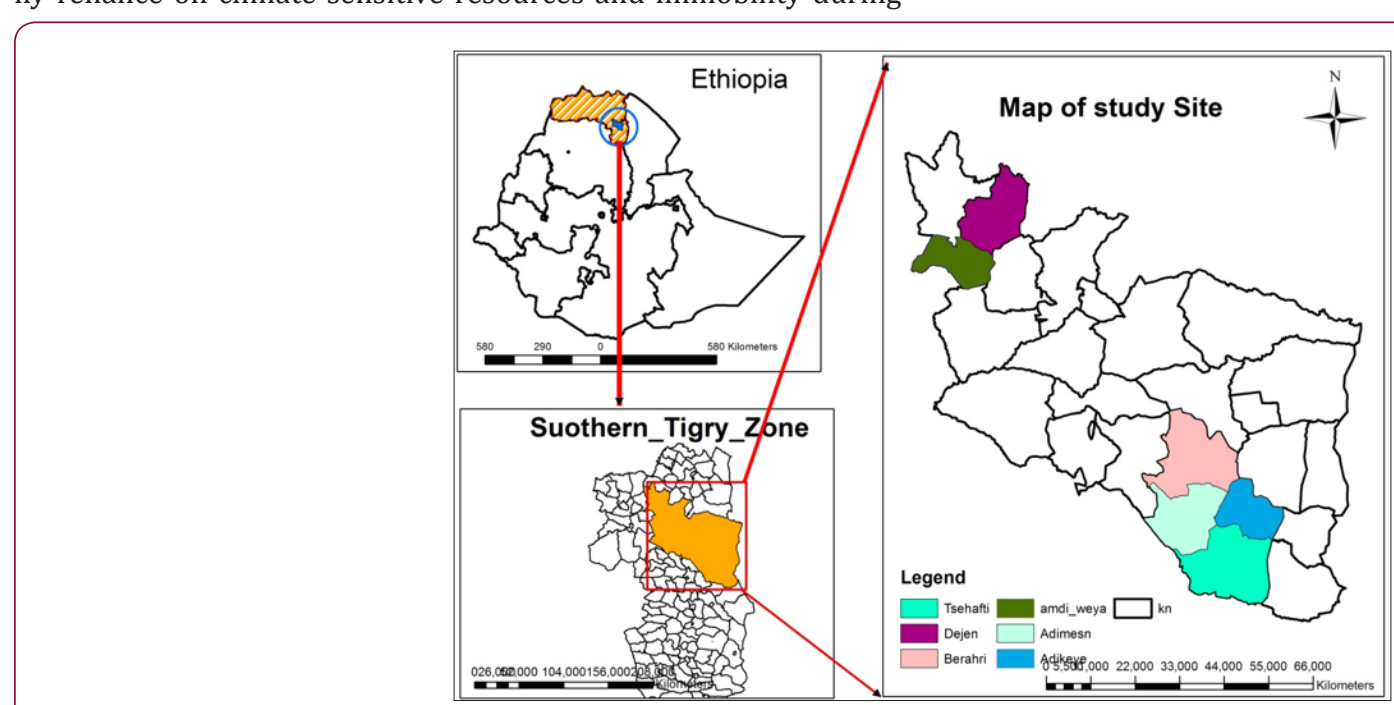

Figure 1: Map of the study area. 


\section{Materials and Methods}

\section{Description of the Study Area}

Hintalo wajerat district is found $748 \mathrm{~km}$ and $35 \mathrm{~km}$ far from the capital city of Ethiopia (Addis Ababa) and capital city of Tigray Regional State (Mekelle) respectively. It is situated lies between latitudes $12^{\circ} 55^{\prime} \mathrm{N}$ to $13^{\circ} 20^{\prime} \mathrm{N}$ and longitudes $39^{\circ} 20^{\prime} \mathrm{E}$ to $39^{\circ} 5^{\prime} 5^{\prime} \mathrm{E} .$. This district is bounded with the east Afar regional state, with the west Samre district, on the South Alaje district, and on the north Enderta district (Figure 1).

\section{Livestock Population}

The livestock population of the district is estimated about 132 , 422 cattle, 44,000 sheep, 498,000 goat, 21,737 equines, 165,600 poultry, and 4,580 camels. The livestock distribution in the six specific study area (kebeles) also estimated about 37666 cattle, 170242 sheep, 6787 goats, 6468 donkeys, 46 mules ,30402 hens, 34 horse and 642 camels (Figure 2). The district covers an area of 2,864.79 Square km. (Source: Hintalo Wajerat District Office of Agriculture and Rural Development, 2015 G.C).

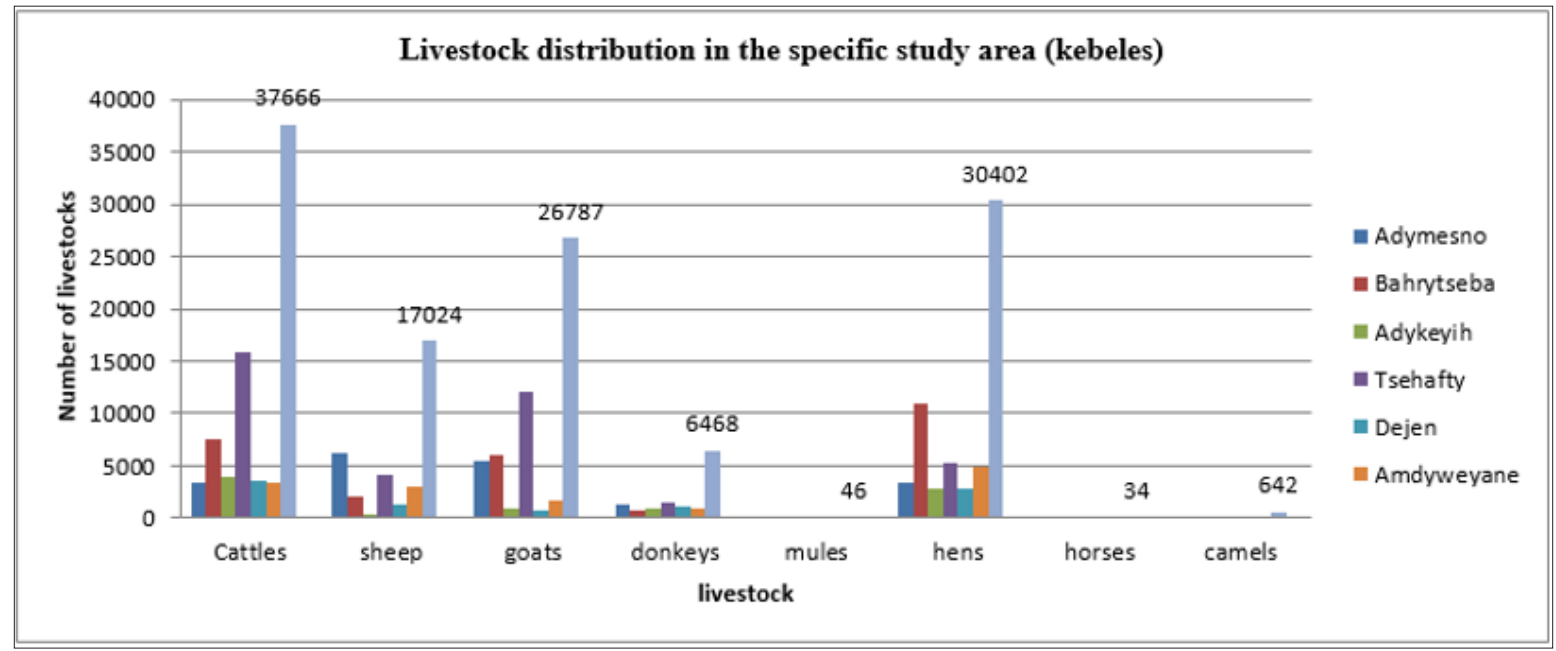

Figure 2: Livestock distribution in the specific study area (kebeles).

\section{Human Population}

This district has an estimated human population of 173,863 (male $47.56 \%$, female $52.44 \%$ ) and 53,863 households with twenty two peasant associations (tabias).and from the total population $90 \%$ of the people are lives in the rural area. (Source: Hintalo Wajerat District finance office, 2010 G.C).

\section{Climate (Agro-Ecology Zone)}

Agro ecology of the district is highland $13.75 \%$, midland $22.5 \%$ and lowland $63.75 \%$ and the study area has summer rainfall (JuneNovember) and dry season (December-may) with mean annual rainfall which ranges from $200-500 \mathrm{~mm}$ and the mean temperature estimated ranges from 16 to $25^{\circ} \mathrm{C}$. (FAO, 2004 G.C).

\section{Land Use Characteristics}

Agriculture is the mainstay of the livelihood of people with a mixed farming system. Livestock plays an integral role for agricultural activity in the district. Livestock also provide meat, milk, cash income and transportation purposes. The livestock species reared in the area include; cattle, sheep, goat, equines, camels and poultry. Animals are kept in protected and communal grazing system. Crops commonly produced are maize, teff, barely, sorghum, wheat, and Beas and beans.

\section{Data Collection}

For this study, data from both primary and secondary data sources were collected and used to achieve the objectives of the study. Primary data were collected from sample households using questionnaire survey, focus group discussion, and key informants' interview. Both qualitative and quantitative data were collected for this study. Qualitative data were obtained using in-depth interviews that included group discussion and key informants. Primary data were mainly related to respondents' demographic characteristics; farmers' perception on climate change; farmers' adaptation practices to climate change; the effect of climate change on livestock production and the barrier of adaptation practices to climate change based on agro ecology. Secondary data such as information on the number of household heads, livestock population and climatic data of the study were collected from kebele administration offices, district agriculture office and National meteorological survey Agency (NMSA).

\section{Household Survey}

The semi-structured questionnaire (close-ended and open-ended questions) was used to generate quantitative data on household characteristics, demographic and educational characteristics of farmers, farmer perceptions on climate change, adaptation strategies to climate change, effect of climate change on livestock productions and barrier to adapt climate change based on agro ecology.

\section{Focus Group Discussion (FGD)}

According to May (1993) the advantage of FGD is that it allows the interaction with a range of key informants and allows the 
researcher to focus on group norms and dynamics around the issue being investigated. According to Gill and Chadwick, 2008), a focus group discussion composed of between six and fourteen members is adequate. Some open-ended questions that help in addressing objectives of the study were prepared for discussions. In this study, FGDs were conducted among the people comprising 6 participants in each group. One FGD was undertaken from each selected kebeles (Table 1). For FGD some questions to collect information were used such as: qualitative information which is related to what type of adaptation strategies were used in their locality, opportunities that help farmers to cope climate change in their area, any support (financial, technical) from concerned bodies for farmers in order to help their effort during the use of adaptation mechanisms.

The contribution of farmer associations in using appropriate adaptation mechanisms and any other relevant information for this study were collected. During this FGD most respondents perceived on climate change occurred and temperature was rising, and rainfall decreased due to climate change over the last fifteen years and they practiced on their livestock to adapt the adverse of climate change. Among most their practices such as; health care their livestock, home feeding, used cross breed, house provision house cleaning and marketing livestock during shocks. The other responds that responded by farmers during FGD in the study area they have some supporters by financial and technical to adapt climate change. Such as, Rest, Catholic, AGP, HHP and farmers' cooperatives. These organizations participating on reforestation, supporting on livestock feed during drought season, on soil and water conservation and on diversification of livestock cross bred.

\section{Key Informants Interview (KII)}

KII was employed in order to support the data which would be collected from household survey. The key informants were those experienced and knowledgeable households on using appropriate adaptation practices on their livestock to adapt climate change in the study area. Twenty four key informants (4 key informants from each peasant association were selected by the help of agricultural office kebeles experts' (Tables 1 \& 2). Informants were interviewed in their homes during weekend time to find them easily and get good information about their experience of adaptation practices on their livestock to adapt climate change. The interviews were conducted in their local language (Tigrigna language). During the interview the different KII respondents perceived that the temperature was rise and the amount of rainfall decreased over the last fifteen years Due to this, they have been used different adaptation practices on their livestock to adapt climate change. Among the most adaptation practices who were used, such as supplementary food for their livestock, provision of house, home feeding, used cross bred livestock, health care their livestock and house cleaned.

Table 1: Participant farmers on the FGD \& KII.

\begin{tabular}{|c|c|c|c|c|c|c|c|c|c|c|c|c|c|}
\hline $\begin{array}{c}\text { Participant } \\
\text { Farmers }\end{array}$ & $\begin{array}{c}\text { Ady } \\
\text { Mesno }\end{array}$ & & $\begin{array}{c}\text { Ady } \\
\text { Keyih }\end{array}$ & & Tsehafty & & $\begin{array}{c}\text { Bahry } \\
\text { Tseba }\end{array}$ & & Dejen & & Aweyanemdy & Participant \\
\hline & Male & female & male & female & male & female & male & female & Male & female & male & female & \\
\hline FGD & 5 & 1 & 4 & 2 & 5 & 1 & 4 & 2 & 3 & 3 & 4 & 2 & 36 \\
\hline KII & 3 & 1 & 3 & 1 & 4 & 0 & 3 & 1 & 3 & 1 & 3 & 1 & 24 \\
\hline
\end{tabular}

Table 2: Distribution of sample sizes in each selected kebele.

\begin{tabular}{|c|c|c|c|}
\hline Agro-Ecology & Total Number of Kebeles Household Heads & Sample Size Taken \\
\hline Highland & Adymesno & $\mathbf{1 6 6 6}$ & $\mathbf{2 0}$ \\
\hline & Bahrytsaba & 2473 & 30 \\
\hline Midland & Amdyweyane & 2440 & 29 \\
\hline Lowland & Dejen & 2102 & 25 \\
\hline & Tsehafty & 2317 & 28 \\
\hline Total & Adykeyih & 1972 & 24 \\
\hline
\end{tabular}

Note: Wereda Hintalo Wajerat Finance Office, 2010 G.C).

\section{Sampling Techniques and Procedures}

For this study, multi-stage sampling procedures were followed. At the first stage, the districts were stratified in to three agroecological zones (namely, highland, midland and low-land). At the second stage, six kebeles (two kebeles from each agro ecological zones) were selected purposively based on their potential livestock population across the three agro ecological zones of the district, frequency of climate related hazard occurrence and accessibility to roads. At the third stage, lists of household heads in the selected kebeles were obtained from Kebele administration offices. Then, the total sample size of the target population at $92 \%$ confidence level and $0.08(8 \%)$ level of precision were determined by using a simplified formula provided by Yamane (1967) and reviewed by Israel, (2012);

$$
n=\frac{N}{1+N(e)^{2}}
$$

Cite this article: Guo R, Brhane W, Genet Y, Gebremedhin Y. Climate Change Adaptation Practices by Ruminant Livestock Producer of in Hintalo Wajerat District Tigray Regional State, Northern Ethiopia. Biomed J Sci \& Tech Res 11(5)-2018. BJSTR. MS.ID.002166. DOI: 10.26717/ BJSTR.2018.11.002166. 
Where $\mathrm{n}$ is the sample size, $\mathrm{N}$ is the population size, and e is the level of precision at $92 \%$ significance level.

In the third stage, Probability Proportional Size (PPS) sampling technique were used to determine the number of sample households from each kebeles. Finally, simple random sampling technique was used to select 156 samples of households from the six kebeles.

\section{Data Analysis}

Data were summarized using descriptive statistics of Microsoft excel and SPSS software version 20 was used to analyze the collected data. Tables and figures (graphs) were used to present the analyzed data. Moreover, independent sample chi-square test and regression were also employed to test the existence of a significant difference between perceived and non- perceived of house hold heads based on the agro ecology on climate change. Descriptive statistics was employed to determine and assess the following aspects: respondents' demographic and institutional characteristics and their attitude towards their climate perception, adaptation practices to adapt climate change, effect of climate change on livestock and barriers to adaptation practices to adapt climate change.

\section{Dependent and Independent Variables}

Dependent Variables: The dependent variables included in the analysis were the adaptation strategies adopted by ruminant livestock producer farmers. The most common adaptation strategies identified during household surveys, focus group discussion and key informant were housing of livestock, livestock marketing during shock (destocking), cross breeding, feeding management and health care practices.

Independent Variables: Independent variables include in the analysis were institutional characteristics, the household head, environmental factors and specifically desired variables were sex and age of the house hold head, marital status, access to information of climate change, educational status of the household head, access to credit, family size, farm size, agro-ecological zone, herd size, access to extension service, farming experience and distance to main market. Independent variables are clearly mentioned in (Table 3).

Table 3: Institutional characteristics of livestock farmers.

\begin{tabular}{|c|c|c|c|c|}
\hline Variable & & Agro Ecology Setting & & Total \\
\hline & Highland & Midland & Lowland & \\
\hline \multicolumn{5}{|l|}{ Sex House Hold Head } \\
\hline Male & $34(68 \% 0$ & $39(72.22 \%)$ & $46(88.46 \%)$ & $119(76.28 \%)$ \\
\hline Female & $16(32 \%)$ & $15(27.78 \%)$ & $6(11.54 \%)$ & $37(23.72 \%)$ \\
\hline \multicolumn{5}{|l|}{ Education } \\
\hline Illiterate & $23(46 \%)$ & $20(37.03 \%)$ & $29(55.77 \%)$ & $72(46.15 \%)$ \\
\hline Tertiary & $1(2 \%)$ & 0 & 0 & $1(0.64 \%)$ \\
\hline Primary School & $22(44 \%)$ & $28(51.85 \%)$ & $22(42.39 \%)$ & $72(46.15 \%)$ \\
\hline Secondary School & $4(8 \%)$ & $5(9.25 \%)$ & $1(1.92 \%)$ & $10(6.41 \%)$ \\
\hline Above Secondary & 0 & $1(1.95 \%)$ & 0 & $1(0.641 \%)$ \\
\hline \multicolumn{5}{|l|}{ Access Credit } \\
\hline Yes & $41(82 \%)$ & $52(96.29 \%)$ & $49(94.23 \%)$ & $142(91.02 \%)$ \\
\hline No & $9(18 \%)$ & $2(3.71 \%)$ & $3(5.77 \%)$ & $14(8.97 \%)$ \\
\hline \multicolumn{5}{|l|}{ Extension Service } \\
\hline No & $14(28 \%)$ & $3(5.55 \%)$ & $6(11.53 \%)$ & $23(14.74 \%)$ \\
\hline Yes & $36(72 \%)$ & $51(94.44 \%)$ & $46(88.46 \%)$ & $133(85.25 \%)$ \\
\hline \multicolumn{5}{|l|}{ Distance to Market } \\
\hline$<5$ & $36(72 \%)$ & $49(90.74 \%)$ & $23(44.23 \%)$ & $108(69.23 \%)$ \\
\hline 6 Up To 10 & $11(22 \%)$ & $5(9.25 \%)$ & $26(50 \%)$ & $42(26.92 \%)$ \\
\hline$>10$ & $3(6 \%)$ & 0 & $3(5.77 \%)$ & $6(3.85 \%)$ \\
\hline \multicolumn{5}{|c|}{ Access to Information } \\
\hline No & $14(18 \%)$ & $3(5.55 \%)$ & $6(11.53 \%)$ & $23(14.74 \%)$ \\
\hline Yes & $36(72 \%)$ & $51(94.44 \%)$ & $46(88.46 \%)$ & $133(85.25 \%)$ \\
\hline \multicolumn{5}{|c|}{ Source of Information } \\
\hline TV Only & $15(30 \%)$ & $9(9.6 \%)$ & $17(31.48 \%)$ & $41(26.28 \%)$ \\
\hline TV, RA, DA & $10(20 \%)$ & $5(9.25 \%)$ & $9(17.30 \%)$ & $24(15.38 \%)$ \\
\hline RA, OBS, DA & $11(22 \%)$ & $23(42.59 \%)$ & $22(42.31 \%)$ & $56(35.9 \%)$ \\
\hline $\mathrm{OB}, \mathrm{DA}$ & $3(6 \%)$ & $15(27.78 \%)$ & $2(3.85 \%)$ & $20(12.85 \%)$ \\
\hline NO Information & $11(22 \%)$ & $2(3.71 \%)$ & $2(3.855 \%)$ & $15(9.62 \%)$ \\
\hline
\end{tabular}

Cite this article: Guo R, Brhane W, Genet Y, Gebremedhin Y. Climate Change Adaptation Practices by Ruminant Livestock Producer of in Hintalo Wajerat District Tigray Regional State, Northern Ethiopia. Biomed J Sci \& Tech Res 11(5)-2018. BJSTR. MS.ID.002166. D0I: 10.26717/ 


\begin{tabular}{|c|c|c|c|c|}
\hline Land Size & & & & \\
\hline 0.125 Up To 0.25 & $11(22 \%)$ & $29(53.7 \%)$ & $12(23 \%)$ & $69(44.23 \%)$ \\
\hline 0.5 Up To 1 & $28(56 \%)$ & $18(33.33 \%)$ & $33(63.46 \%)$ & $68(43.59 \%)$ \\
\hline$>1$ & $17(34 \%)$ & $7(12.96 \%)$ & $6(1.92 \%)$ & $11.54 \%)$ \\
\hline No Land & $05(10 \%)$ & 0 & & $8(7.05 \%)$ \\
\hline Herd Size & & & $29(5.13 \%)$ \\
\hline No Livestock & $6(12 \%)$ & $33(61.11 \%)$ & $14(26.92 \%)$ & $84(53.85 \%)$ \\
\hline$<5(1)$ & $22(44 \%)$ & $9(16.66 \%)$ & $5(9.62 \%)$ & $40(25.64 \%)$ \\
\hline 6 Up To 10 & $17(34 \%)$ & $6(11.11 \%)$ & $1(1.92 \%)$ & $14(8.97 \%)$ \\
\hline 11 Up To 15 & $3(6 \%)$ & $2(3.7(\%)$ & $3(5.77 \%)$ & $4(2.56 \%)$ \\
\hline 16 Up To 20 & $1(2 \%)$ & $2(3.7 \%)$ & $6(3.85 \%)$ \\
\hline 21 Up To25 & $1(2 \%)$ & & \\
\hline
\end{tabular}

\section{Results and Discussion}

This part comprises the findings of the study and their brief respective discussion. Mainly, it includes the farmers' perception on climate change with different agro ecologies; farmers' adaptation practices to climate change and compare their adaptive strategies in different agro ecologies; the effect of climate change on livestock production and identify constraints to climate change adaptation practices.

\section{Socio Economic Characteristics of Respondents}

Socio economic characteristics of the households are shown in (Table 3). One hundred fifty six households in three agro-ecological settings were enrolled in this study. Among these households 119 (76.28\%) were male-headed households; whereas the rest 37 (23.72\%) were female-headed.

\section{Access to Credit Service}

Significant number of the households 142(91\%) had access to credit, and $147(94.23 \%)$ have own land and they participated in farm activities (Table 3). As confirmed by key informants and group discussants, most farmers in the midland area such as Dejen kebeles have fertile farmlands and better opportunity to grow different crops, vegetables and livestock feeds or pastures using irrigation practices.

\section{Access to Extension Service}

Generally, 133 (85.25\%) respondents had access to extension services on climate change. As compared agro ecological setting, the midland respondents $51(94.44 \%)$ had access to extension services than the two agro ecology respondents. Due to this there is statistically significant different on access extension services among the three agro ecological setting $(\mathrm{p}<.005)$.

\section{Distance to Markets}

Distance to market is one of the important things for farmers climate adaptation opportunity; that means when the markets nearby to the farmers' is easy to buy animal feeds and for animal marketing during shock. As shown in (Table 3), 108 (69.23\%) more than half of the respondents had marketing access nearby their local area $(<5 \mathrm{Kms})$.

\section{Access to Climate Change Information}

Out of the 156 conducted farmers', 133 (85.25\%) had access on climate change information and they have different source of climate information. Among their sources of climate information, the most sources that responded by the farmers, 56 (35.9\%), own observation, radio and development agent.

\section{Purpose of Keeping Cattle and their Importance in the Study Area}

Ruminant livestock production is one of the most important agricultural sectors for rural and urban communities. During the questioner's survey in the specific study area indicates, farmers' respond on purpose of ruminant livestock production has responded that farmers were kept their ruminant livestock for different purposes. Such as, for consumption only (5.12\%), for income only (4.5\%) and for both consumption and income (90.38\%\%), respectively.

\section{Farmers Perception on Climate Change}

Farmers' were asked about their perception whether climate is changing or not over the last 30 years. As shown in (Table 4). out of 156 respondents 150 (96.15\%) farmers 'perceived that climate change is indeed occurring and 6(3.85\%) respondents also none perceived whether climate is changed or not. This study results agrees with findings farmers' response towards perception on climate change is consistent with other studies. Studies conducted by Abraham et al. and Mengestu $[35,8,10]$ in Ethiopia reported that the temperature is rising, and rainfall amount is decreasing due to climate change. Studies conducted in other African countries like South Africa [36-38] also documented similar findings with this study on farmers' perception about climate change.

\section{Causes of Climate Change}

As written by different previous researchers; cause of climate change had classified natural and human activities. In this study also, the most causes of climate change responded by the respondents revealed that anthropogenesis and human activities. These common causes such as; overgrazing $126(80.8 \%)$, deforestation $110(70.5 \%)$, urbanization 106 (67.9\%), population growth 99 (63.5\%), natural variability 96(61.1\%), Agriculture 82(52.6\%), 
Poor waste management 72(46.8\%), Industry 59(37.8\%) transportation 55(35.3\%) and mining 50(32.1\%) respectively [39-49].

\section{Climate Change Indicators}

Among the climate change indicators, temperature and rainfall were considered as parameters for the analysis in this study. The responses from respondents in relation to changes in temperature and rainfalls across three agro-ecological zones are depicted in Figure 7 and Figure 12 respectively. Most of the respondents acknowledged that there is rise in temperature and decline in rainfall amount. The other climate change indicators that mentioned by the farmers during the questioner's surveys included, reduced crop yields (crop failure) Limited availability of water, Reduction in soil fertility, reduced indigenous biodiversity, increased food prices and Conflict over scarce resources (water...). As showed in above Table 4, the farmers' perception on climate change based on sex* agro ecology categories indicates that, the respondents perceived whether climate is changed or not during the questionnaires survey in the study area. Due to this when compared the perception on climate change based on sex categories; out of 119 male respondents, $117(98.31 \%)$ of male farmers and out of 39 female respondents $33(89.19 \%)$ of female farmers were revealed that perceived climate was changed over last 30 years respectively. The rest $4(10.8 \%)$ female and $2(1.68 \%)$ male respondents were not perceived whether climate is changed or not [49-59].

Table 4: Purpose of livestock rearing by farmers in the study area.

\begin{tabular}{|c|c|c|c|c|c|}
\hline Sex & & & Purpose of Livestock & Botal \\
\hline & & Consumption & Income & 34 & 37 \\
\hline Female & Count & 2 & 1 & $91.9 \%$ & $23.7 \%$ \\
\hline Male & $\%$ & $5.4 \%$ & $6.7 \%$ & 107 & $79 \%$ \\
\hline & Count & 6 & $5 \%$ & 141 & $76.3 \%$ \\
\hline Total & Count & 8 & 7 & $90.38 \%$ & 156 \\
\hline
\end{tabular}

These non-perceived respondents may be due to educational level, lack of awareness and lack of information on climate change. So this indicates that, the climate perception between the perceived and non-perceived respondents on climate change was there is statistically significant different $(\mathrm{p}<.029)$. The climate change perception among three agro ecology also indicates, there is some different. While, except in the highland the rest two agro ecology there is not significant different on climate perception. The above
(Table 5) indicates, the farmers' perception on climate change based on age categories between 36-45 had more perceived than other age categories. This may be due to the educational status of farmers' and their climate perceptions based on age categories had statistically significant different $(\mathrm{P}<0.05)$. While, the farmers' perception on climate change based on three agro ecological setting was there is not significant different and this may be due to their similar awareness on all the three agro ecology [59-69].

Table 5: Farmers climate perception based on Sex*agro ecology.

\begin{tabular}{|c|c|c|c|c|c|}
\hline Agro Ecology & & Sex & & Total & $\mathbf{X}^{2}$ \\
\hline & & Female & Male & & \\
\hline & No & 3 & 0 & 3 & \\
\hline \multirow[t]{3}{*}{ Highland } & Yes & 13 & 34 & 47 & .029 \\
\hline & Sub Total & 16 & 34 & 50 & \\
\hline & No & 1 & 1 & 2 & .482 \\
\hline \multirow[t]{3}{*}{ Midland } & Yes & 14 & 38 & 52 & \\
\hline & Sub Total & 15 & 39 & 54 & \\
\hline & No & 0 & 1 & 1 & .885 \\
\hline \multirow[t]{5}{*}{ Lowland } & Yes & 6 & 45 & 51 & \\
\hline & Sub Total & 6 & 46 & 52 & \\
\hline & No & 4 & 2 & $6(3.85 \%)$ & \\
\hline & Yes & 33 & 117 & $150(96.15)$ & .029 \\
\hline & Grand Total & 37 & 119 & 156 & \\
\hline
\end{tabular}

The effect of the sex of the respondents on perception of temperature variability and trends of temperature in the study area is given in Figure 3. Most of the respondents were perceived that temperature was increased. There is difference between the male and female on climate perception and this indicating that, 98(82.35\%) male respondents perceived on climate change than female $24(64.86 \%)$ counter parts. The respondents which did not have any perception about climate changes were $4(10.8 \%)$ females 
and $2(1.7 \%)$ males. while about $7(18.9 \%)$ females and $7(5.88 \%)$ males reported agreed that, decreasing trends of temperature in the study area. On top of this few 2 (5.4\%) females and $12(10.8 \%)$ males perceived no change in temperature in the study area. The age of the respondents had affected the perception of farmers on climate change through variability in temperature as shown in Figure 4, the age categories between 36-45 respondents perceived that, temperature was increased in the thirty years than other respondents and this may be due to educational level [69-79].

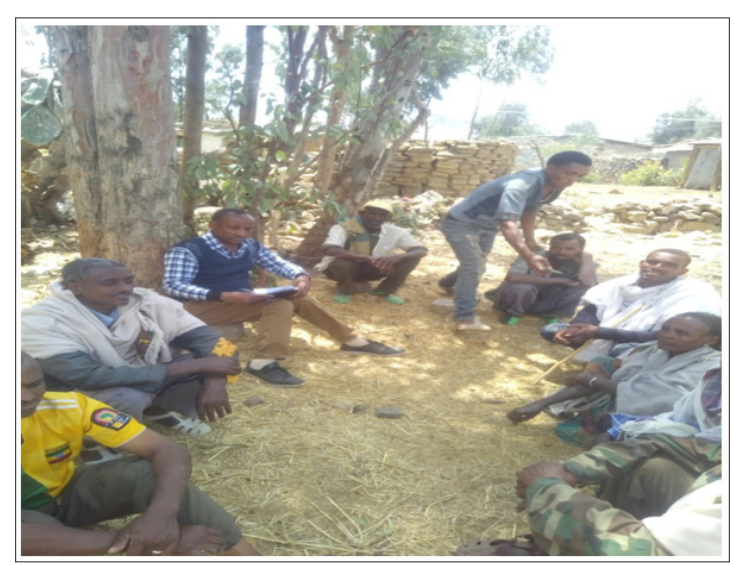

Figure 3: Group discussion, on climate perception and adaptation methods in kebele dejen. Group discussion, 2018.

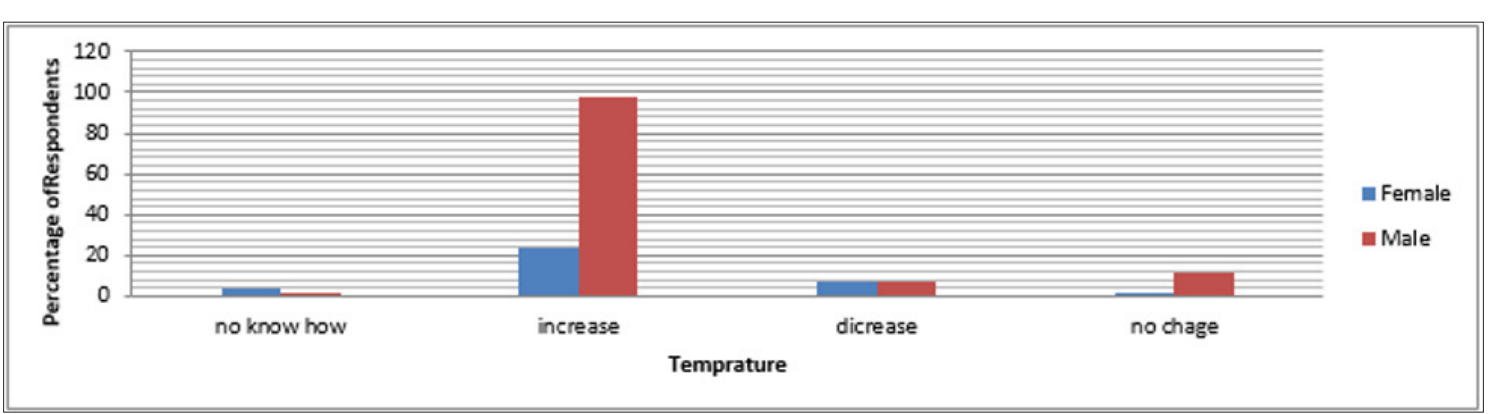

Figure 4: Climate perception based on sex-trends of temperature.

While the age categories between 16-25 and >55 were have less perceived on climate change through variability or change in temperature. Farmer's perception through climate change in temperature- based on agro ecology as shown Figure 5, Most of the respondents' perceived that, temperature is increased. Especially the lowland respondents perceived than midland and highland respondents on the rising of temperature. It was observed that most of the respondents reported temperature is increasing. The respondents from lowland area perceived more than midland and highland on the rising of temperature. As shown in Figure 6, the perception confirmed by scientific description of meteorology data from average monthly maximum and minimum temperature was increased and the same that during the questionnaires survey respondents perceived on the rising of temperature. (Tigray metrological data of the study area. 2018) [79-83]. As shown in Figure 7, based on a scientific description of meteorology agency the trends of annual average temperature were increased. The farmers' perception on climate change during questionnaire survey also indicates, that agreed the trends of annual average temperature.

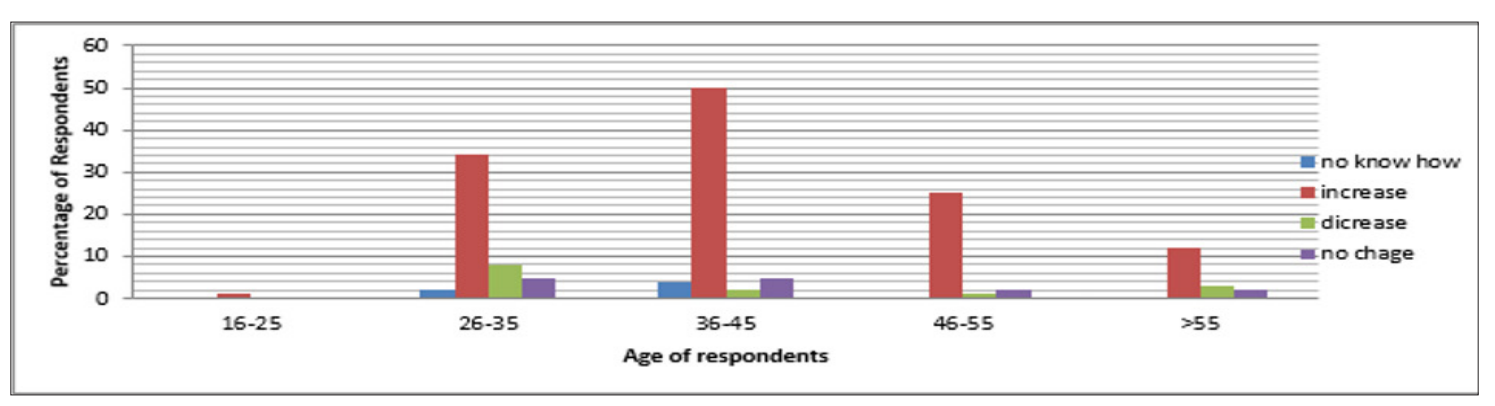

Figure 5: Effect of age of the respondents on the percetion variability of temprature. 


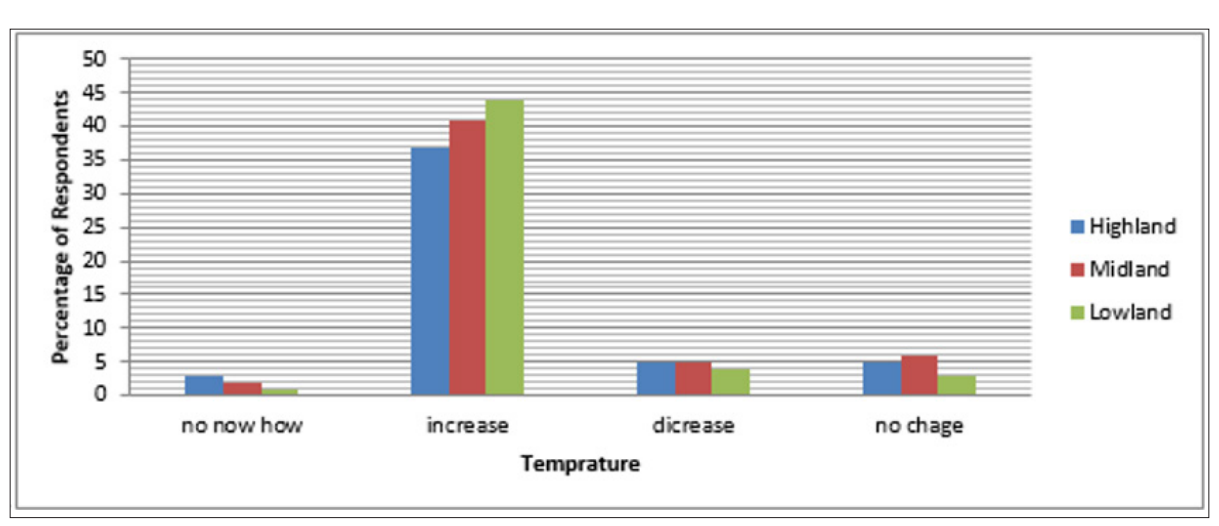

Figure 6: Perception of farmers to change in temperature in the study area.

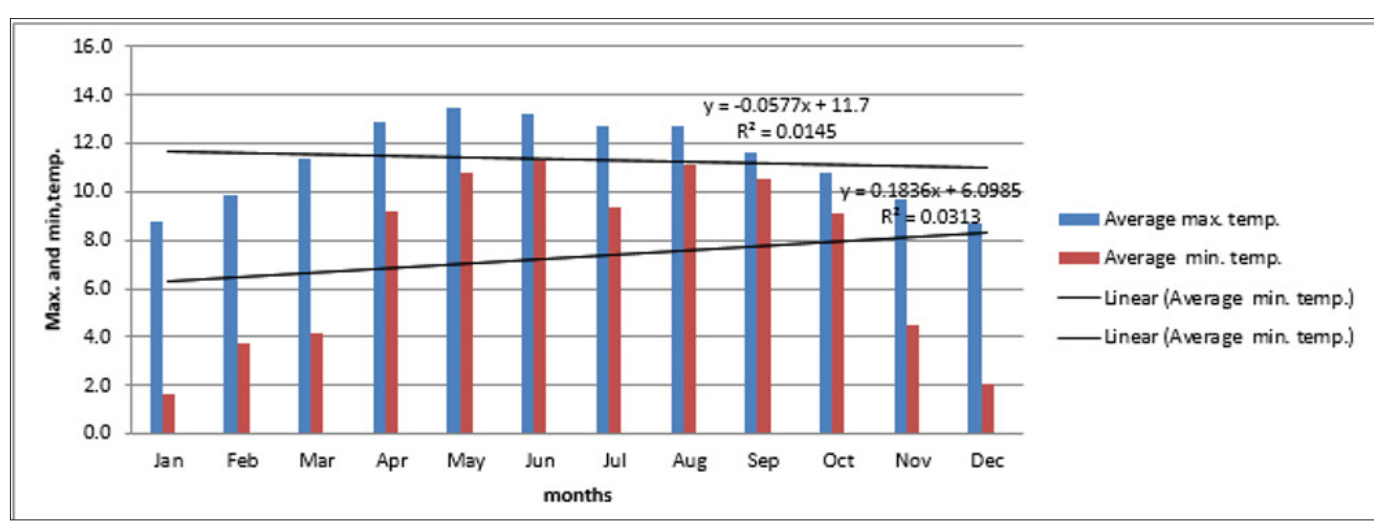

Figure 7: Average monthly maximum and minimum temperature in study area.

Such as among hundred and fifty six farmers'122 (78.2\%) respondents were perceived or said that, trends of temperature were increased due to climate change. While 14 (9\%) of respondents were perceived decreased in temperature whereas 14 $(9 \%)$ of respondents perceived no change in temperature and the other $6(3.85 \%)$ respondents said that, no know how whether the temperature was increased or decreased over the thirty years due to climate change. When compared the scientifically metrological data annual maximum and minimum temperature results with farmers responds during questionnaire survey on the trends of temperature, they agreed the rising of temperature on over the three decades. (Tigray metrological data of the study area. 2018).

As shown in Figure 8, decreasing trends of precipitation was reported by both sexes of the respondents in the study area as compared to the respondents. Similarly, the perception of all age categories of the farmers on trends of precipitation indicated decreasing in amount and frequency in the study area. When farmers were compared based on sex and age categories, male farmers and female farmers with the age classes between 36-45 years had perceived that decreasing trends of rain fall than the other respondents' age categories (Figure 9). This indicates, may be due to their educational status, accesses on climate information and awareness on climate change. As shown in Figure 10, the change in rainfall amount due to climate change as reported by farmers from three different agro-ecological settings, the midland respondents had reported that the precipitation was decreased as compared to respondents from the lowland and highland agro-ecologies.

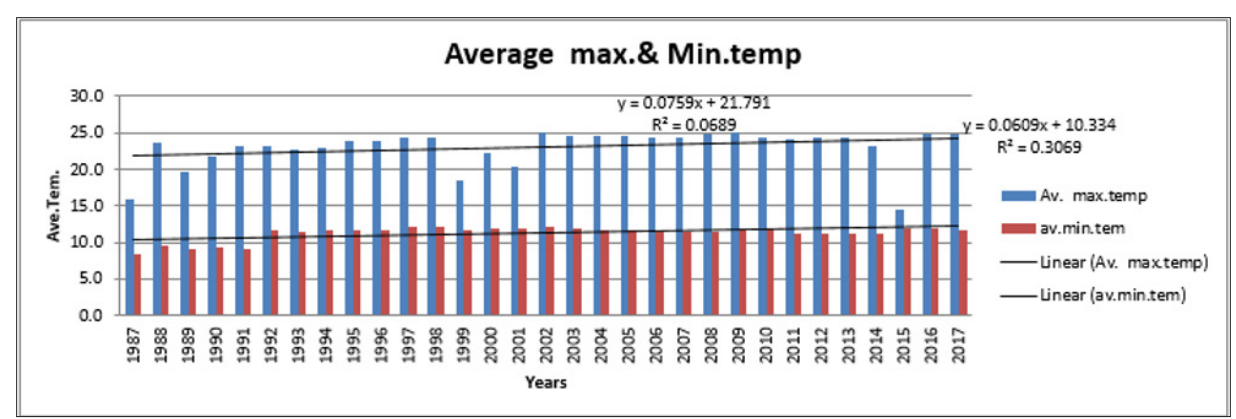

Figure 8: Trends of mean annual av max and min temperature in study area (1987-2017). 


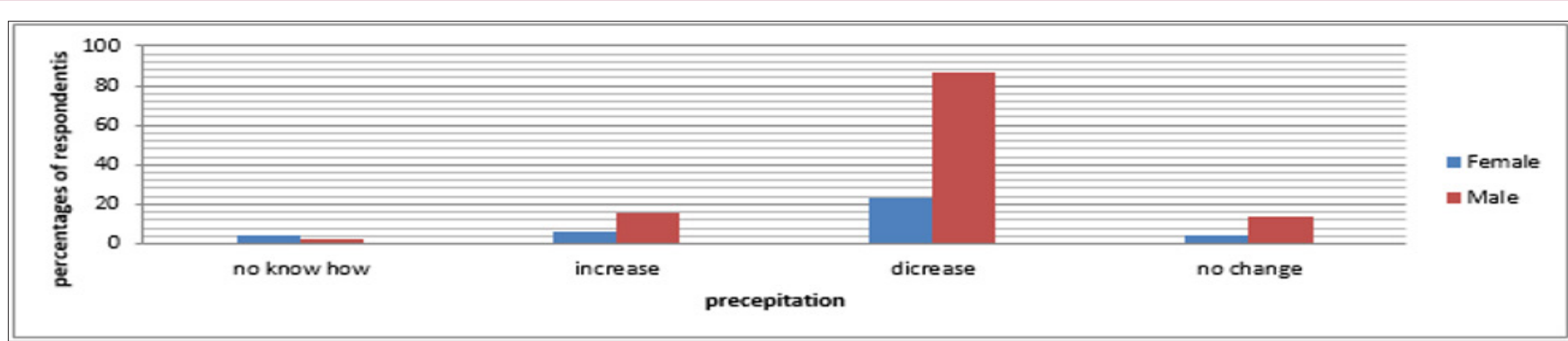

Figure 9: Effect of sex on farmers' perception on climate change based on precipitation.

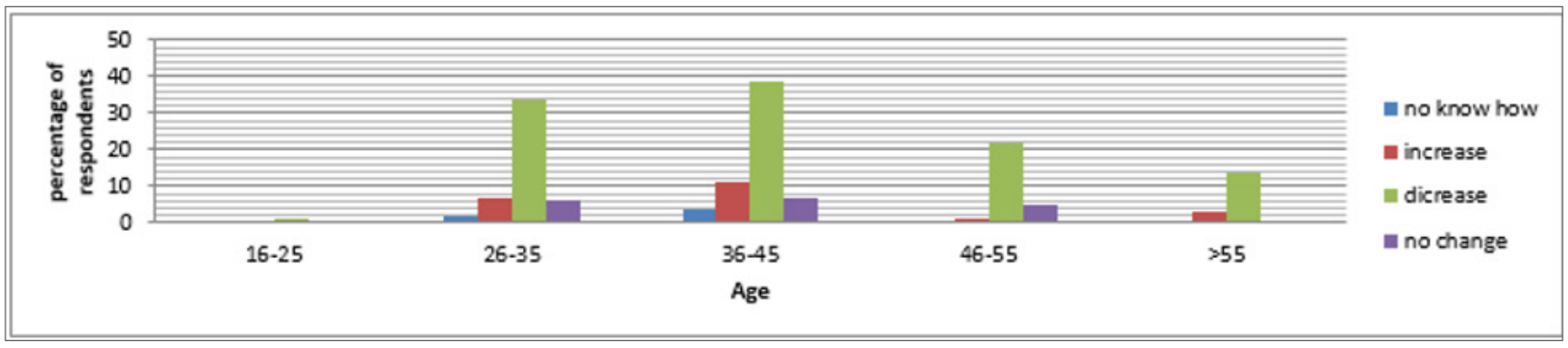

Figure 10: Effect of the age on farmers' perception of climate change based on precipitation.

While, there is no statistically significial different among three agro ecology setting on the trends of precipitation. During the questionnaires survey, the perception of the farmers on the trends of precipitation was reported as declining in amount and intermittent in frequency of occurrence. While metrological agency in the studied area reported that the trend monthly amount of rain fall showed slightly increasing (Figure 11). It was observed that there were agreements between perception of the farmers during questionnaires survey and meteorology data on the amount of rain fall in the study area. Due to this, farmers perceived that the rain fall was observed to decrease both in amount and frequency of occurrence and the NMA reported also indicates the amount of annual rain fall showed decreased trend with reduced frequency (Figure 12).

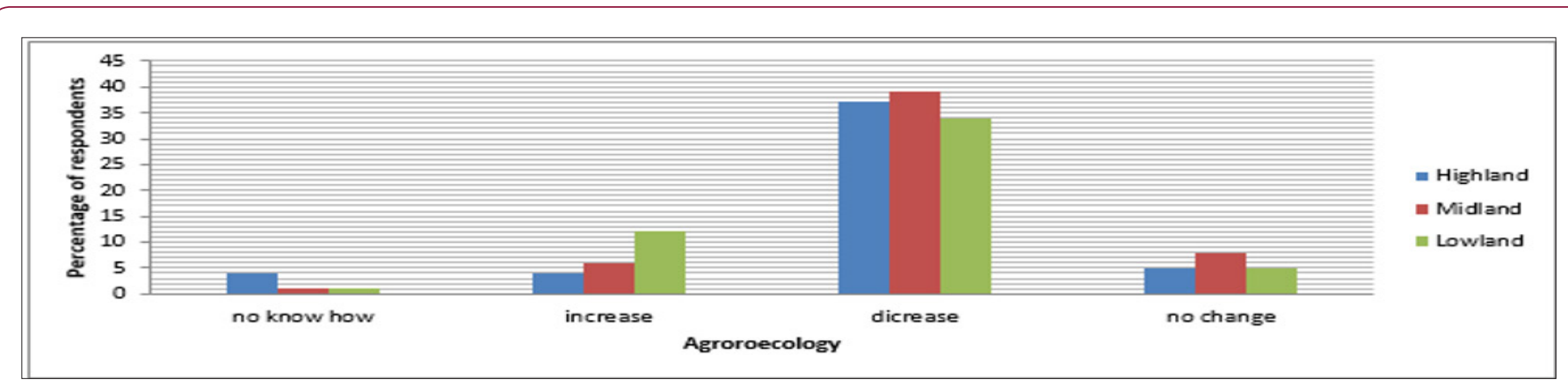

Figure 11: Effect of agro ecology on amount rain fall as perceived by respondent farmers.

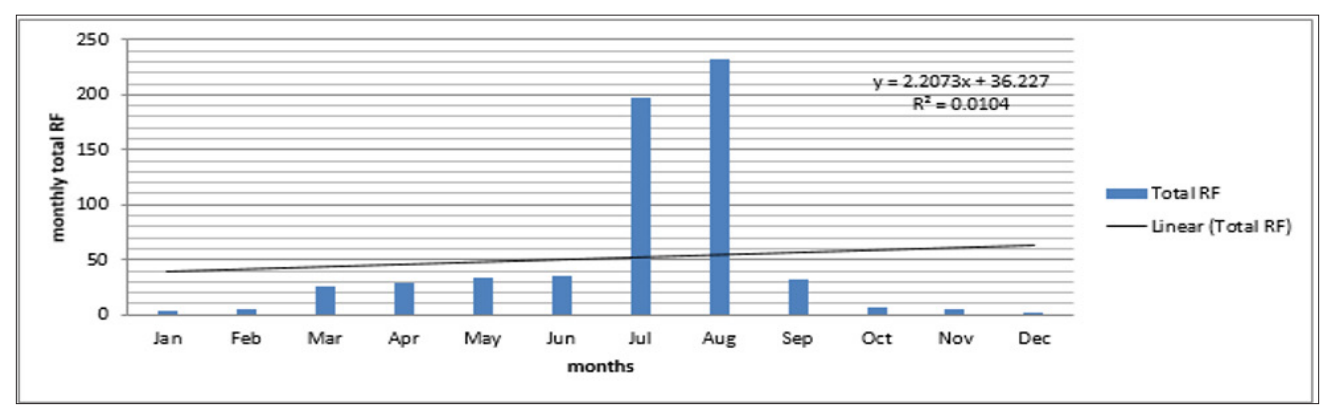

Figure 12: Trend of Mean monthly amount of total rain falls in study area.

Tigray metrological data of the study area 2018.

Cite this article: Guo R, Brhane W, Genet Y, Gebremedhin Y. Climate Change Adaptation Practices by Ruminant Livestock Producer of in Hintalo Wajerat District Tigray Regional State, Northern Ethiopia. Biomed J Sci \& Tech Res 11(5)-2018. BJSTR. MS.ID.002166. DOI: 10.26717/ BJSTR.2018.11.002166. 
Effect of Climate Change on Livestock Production and Animal Feed Production

As showed in Table 6, the perceptions of farmers on the effect of climate change on livestock and livestock feed production was indicates, most of the respondents agreed that climate change had negatively affected livestock and on animal feed production in the study area. Especially the female respondents 35 (94.59\%) were perceived than male $110(92.44 \%)$ on the effect of climate change on livestock production and animal feed production. Even, the farmers perception on the effect of climate change on livestock production and animal feed production was different between the female and male respondents on different agro ecology. While, there is no significant different between the female and male respondents on the response of effect of climate change on livestock production and feed production in the study area. This may be due to their similar awareness's. The respondents based on age categories that reported their perception on the effect of climate change on

Table 6: Farmers climate perception based on Age*agro ecology. livestock production and animal feed production.

Due to this as shown in Tables 6-8, the age between 36-45 years old were more perceived or agreed that, the adverse effect of climate change on livestock production than the other age categories. When compared the perception of farmers on the effect of climate change on livestock production and animal feeds based on different agro ecology indicates there is some different on their climate perception Such as, midland.52 (96.29\%), lowland 50 (96.15\%) and highland $43(86 \%)$ respectively. While, there is no significant difference on farmers' perception on the adverse effects of climate change on livestock production and animal feeds among the three agro ecology. This may be due to their similar awareness on climate change on the three agro ecology setting. Table 9 showed that, the farmers' perception on the effects of climate change on livestock production based on sex. Due to this most of respondents 137 $(87.8 \%)$ agreed that, the livestock production decreased by the adverse effects of climate change.

\begin{tabular}{|c|c|c|c|c|c|c|c|c|}
\hline Agro Ecology & & & & Age & & & Total & $\mathrm{X} 2$ \\
\hline & & $16-25$ & 26-35 & $36-45$ & 46-55 & $>55$ & & \\
\hline \multirow[t]{3}{*}{ Highland } & No & & 1 & 2 & 0 & 0 & 3 & .869 \\
\hline & Yes & & 14 & 24 & 7 & 2 & 47 & \\
\hline & Sub Total & & 15 & 26 & 7 & 2 & 50 & \\
\hline \multirow[t]{3}{*}{ Midland } & No & 0 & 1 & 1 & 0 & 0 & 2 & .932 \\
\hline & Yes & 1 & 23 & 15 & 7 & 6 & 52 & \\
\hline & Sub Total & 1 & 24 & 16 & 7 & 6 & 54 & \\
\hline \multirow[t]{6}{*}{ Lowland } & No & & 0 & 1 & 0 & 0 & 1 & .621 \\
\hline & Yes & & 10 & 18 & 14 & 9 & 51 & \\
\hline & Sub Total & & 10 & 19 & 14 & 9 & 52 & \\
\hline & No & 0 & 2 & 4 & 0 & 0 & 6 & .548 \\
\hline & Yes & 1 & 47 & 57 & 28 & 17 & 150 & \\
\hline & Grand Total & 1 & 49 & 61 & 28 & 17 & 156 & \\
\hline
\end{tabular}

Table 7: Farmers perception on the effect of c/change on livestock production and animal feed production based on sex*agro ecology.

\begin{tabular}{|c|c|c|c|c|c|}
\hline Agro Ecology & & Sex & & Total & $\mathrm{X} 2$ \\
\hline & & Female & Male & & \\
\hline & No & 2 & 5 & 7 & .604 \\
\hline \multirow[t]{3}{*}{ Highland } & Yes & 14 & 29 & 43 & \\
\hline & Sub Total & 16 & 34 & 50 & \\
\hline & No & 0 & 2 & & \\
\hline \multicolumn{6}{|l|}{2} \\
\hline \multirow[t]{3}{*}{ Midland } & Yes & 15 & 37 & 52 & .518 \\
\hline & Sub Total & 15 & 39 & 54 & \\
\hline & No & 0 & 2 & 2 & \\
\hline \multirow[t]{5}{*}{ Lowland } & Yes & 6 & 44 & 50 & .781 \\
\hline & Sub Total & 6 & 46 & 52 & \\
\hline & No & 2 & 9 & 11 & \\
\hline & Yes & 35 & 110 & 145 & .495 \\
\hline & Grand Total & 37 & 119 & 156 & \\
\hline
\end{tabular}

Cite this article: Guo R, Brhane W, Genet Y, Gebremedhin Y. Climate Change Adaptation Practices by Ruminant Livestock Producer of in Hintalo Wajerat District Tigray Regional State, Northern Ethiopia. Biomed J Sci \& Tech Res 11(5)-2018. BJSTR. MS.ID.002166. DOI: 10.26717/ 
Table 8: Farmers perception on the adverse effects of climate change on livestock production and animal feed production age*agro ecology basis.

\begin{tabular}{|c|c|c|c|c|}
\hline Agro Ecology & Age & Effect of Climate Change on Livestock & & Total \\
\hline & & No & Yes & \\
\hline & $26-35$ & 3 & 12 & 15 \\
\hline & $36-45$ & 2 & 24 & 26 \\
\hline \multirow[t]{6}{*}{ Highland } & $46-55$ & 1 & 6 & 7 \\
\hline & $>55$ & 1 & 1 & 2 \\
\hline & Total & 7 & 43 & 50 \\
\hline & $16-25$ & 0 & 1 & 1 \\
\hline & $26-35$ & 0 & 24 & 24 \\
\hline & $36-45$ & 1 & 15 & 16 \\
\hline \multirow[t]{5}{*}{ Midland } & $46-55$ & 0 & 7 & 7 \\
\hline & $>55$ & 1 & 5 & 6 \\
\hline & Total & 2 & 52 & 54 \\
\hline & $26-35$ & 1 & 9 & 10 \\
\hline & $36-45$ & 1 & 18 & 19 \\
\hline \multirow[t]{6}{*}{ Lowland } & $46-55$ & 0 & 14 & 14 \\
\hline & $>55$ & 0 & 9 & 9 \\
\hline & Total & 2 & 50 & 52 \\
\hline & $16-25$ & 0 & 1 & 1 \\
\hline & $26-35$ & 4 & 45 & 49 \\
\hline & $36-45$ & 4 & 57 & 61 \\
\hline \multirow[t]{3}{*}{ Total } & $46-55$ & 1 & 27 & 28 \\
\hline & $>55$ & 2 & 15 & 17 \\
\hline & Total & 11 & 145 & 156 \\
\hline
\end{tabular}

Table 9: Farmers perception on the adverse effects of climate change on livestock production based on sex.

\begin{tabular}{|c|c|c|c|c|c|c|}
\hline Sex & & & Animal Products & & Total \\
\hline & & No Know How & Increase & Decrease & No Change & \\
\hline Female & Count & 4 & 2 & 28 & 3 & 37 \\
\hline & $\%$ & $10.8 \%$ & $5.4 \%$ & $75.67 \%$ & $8.022 \%$ & $23.7 \%$ \\
\hline Male & Count & 2 & 4 & 109 & 4 & 719 \\
\hline & $\%$ & $1.68 \%$ & $3.36 \%$ & $91.59 \%$ & $3.36 \%$ & 7 \\
\hline Total & Count & 6 & 6 & 137 & $4.3 \%$ & 156 \\
\hline & $\%$ & $3.8 \%$ & $3.8 \%$ & $87.8 \%$ & $4.5 \%$ & $100.0 \%$ \\
\hline
\end{tabular}

Table 10: Farmers perception the effects of climate change on livestock feed production based on sex.

\begin{tabular}{|c|c|c|c|c|c|c|}
\hline Sex & & & Feed Production & & & Total \\
\hline & & No Know How & Increase & Decrease & No Change & \\
\hline \multirow[t]{2}{*}{ Female } & Count & 4 & 1 & 28 & 4 & 37 \\
\hline & $\%$ & $10.8 \%$ & $0.6 \%$ & $75.67 \%$ & $10.8 \%$ & $23.7 \%$ \\
\hline \multirow[t]{2}{*}{ Male } & Count & 2 & 6 & 107 & 4 & 119 \\
\hline & $\%$ & $1.68 \%$ & $3.36 \%$ & $89.91 \%$ & $3.36 \%$ & $76.3 \%$ \\
\hline \multirow[t]{2}{*}{ Total } & Count & 6 & 7 & 135 & 8 & 156 \\
\hline & $\%$ & $3.8 \%$ & $4.5 \%$ & $86.5 \%$ & $5.1 \%$ & $100.0 \%$ \\
\hline
\end{tabular}


When compared the female and male perception on the effects of climate change on livestock production, the male $(91.59 \%)$ was agreed on decreased the animal products by the adverse effects of climate change than the female $(75.67 \%)$ respondents. Table 10 showed that, the farmers' perception on the effects of climate change on livestock feed production based on sex. Due to this most of respondents135 (86.5\%) agreed that, the feed production decreased by the effects of climate change. When compared the female and male perception on the effects of climate change on livestock feed production, the male (89.91\%) was agreed on decreased the livestock feed production by the effects of climate change than the female (75.67\%) respondents. Table 11 showed that, the farmers' perception on the adverse effects of climate change on livestock production based on categories Due to this among the different age categories the farmers who have the age between 36-45 old that more agreed the livestock production decreased by the adverse effects of climate change than other age categories.

Table 11: Farmers perception on the adverse effects of climate change on livestock production based on age.

\begin{tabular}{|c|c|c|c|c|c|c|}
\hline Age & & & Livestock Production & & & Total \\
\hline & & No Know How & Increase & Decrease & No Change & \\
\hline \multirow[t]{2}{*}{$16-25$} & Count & 0 & 0 & 1 & 0 & 1 \\
\hline & $\%$ & $0.0 \%$ & $0.0 \%$ & $0.6 \%$ & $0.0 \%$ & $0.6 \%$ \\
\hline \multirow[t]{2}{*}{$26-35$} & Count & 2 & 2 & 43 & 2 & 49 \\
\hline & $\%$ & $1.3 \%$ & $1.3 \%$ & $27.6 \%$ & $1.3 \%$ & $31.4 \%$ \\
\hline \multirow[t]{2}{*}{$36-45$} & Count & 4 & 2 & 53 & 2 & 61 \\
\hline & $\%$ & $2.6 \%$ & $1.3 \%$ & $34.0 \%$ & $1.3 \%$ & $39.1 \%$ \\
\hline \multirow[t]{2}{*}{$46-55$} & Count & 0 & 2 & 23 & 3 & 28 \\
\hline & $\%$ & $0.0 \%$ & $1.3 \%$ & $14.7 \%$ & $1.9 \%$ & $17.9 \%$ \\
\hline \multirow[t]{2}{*}{$>55$} & Count & 0 & 0 & 17 & 0 & 17 \\
\hline & $\%$ & $0.0 \%$ & $0.0 \%$ & $10.9 \%$ & $0.0 \%$ & $10.9 \%$ \\
\hline \multirow[t]{2}{*}{ Total } & Count & 6 & 6 & 137 & 7 & 156 \\
\hline & $\%$ & $3.8 \%$ & $3.8 \%$ & $87.8 \%$ & $4.5 \%$ & $100.0 \%$ \\
\hline
\end{tabular}

This may be due to their educational status and their awareness on the adverse effect of climate change on livestock production. Tables $12 \& 13$ showed that, the farmers' perception on the adverse effects of climate change on livestock feed production based on age categories Due to this among the different age categories the farmers who have the age between 36-45 old's that more agreed the livestock feed production decreased by the adverse effects of climate change than other age categories. This may be due to their educational status and their awareness on the adverse effect of climate change on livestock feed production.

Table 12: Farmers perception the effects of climate change on livestock feed production based on age.

\begin{tabular}{|c|c|c|c|c|c|c|}
\hline Age & & & Livestock Feed Production & & & Total \\
\hline & & No Know How & Increase & Decrease & No Change & \\
\hline \multirow[t]{2}{*}{$16-25$} & Count & 0 & 0 & 1 & 0 & 1 \\
\hline & $\%$ & $0.0 \%$ & $0.0 \%$ & $0.6 \%$ & $0.0 \%$ & $0.6 \%$ \\
\hline \multirow[t]{2}{*}{$26-35$} & Count & 2 & 1 & 40 & 6 & 49 \\
\hline & $\%$ & $1.3 \%$ & $0.6 \%$ & $25.6 \%$ & $3.8 \%$ & $31.4 \%$ \\
\hline \multirow[t]{2}{*}{$36-45$} & Count & 4 & 5 & 51 & 1 & 61 \\
\hline & $\%$ & $2.6 \%$ & $3.2 \%$ & $32.7 \%$ & $0.6 \%$ & $39.1 \%$ \\
\hline \multirow[t]{2}{*}{$46-55$} & Count & 0 & 1 & 26 & 1 & 28 \\
\hline & $\%$ & $0.0 \%$ & $0.6 \%$ & $16.7 \%$ & $0.6 \%$ & $17.9 \%$ \\
\hline \multirow[t]{2}{*}{$>55$} & Count & 0 & 0 & 17 & 0 & 17 \\
\hline & $\%$ & $0.0 \%$ & $0.0 \%$ & $10.9 \%$ & $0.0 \%$ & $10.9 \%$ \\
\hline \multirow[t]{2}{*}{ Total } & Count & 6 & 7 & 135 & 8 & 156 \\
\hline & $\%$ & $3.8 \%$ & $4.5 \%$ & $86.5 \%$ & $5.1 \%$ & $100.0 \%$ \\
\hline
\end{tabular}

Cite this article: Guo R, Brhane W, Genet Y, Gebremedhin Y. Climate Change Adaptation Practices by Ruminant Livestock Producer of in Hintalo Wajerat District Tigray Regional State, Northern Ethiopia. Biomed J Sci \& Tech Res 11(5)-2018. BJSTR. MS.ID.002166. D0I: 10.26717/ BJSTR.2018.11.002166. 
Table 13: Adaptation options used by livestock producer based on agro ecology.

\begin{tabular}{|c|c|c|c|c|}
\hline Adaptation Practices & & Agro Ecology Setting & Lowland & Total \\
\hline & Highland & Midland & $39(75 \%)$ & $120(76.92 \%)$ \\
\hline Provision of shade & $40(80 \%)$ & $41(75.92 \%)$ & $42(80.77 \%)$ & $128(82.05 \%)$ \\
\hline Clean of shade & $37(74 \%)$ & $49(90.74 \%)$ & $20(38.46 \%)$ & $41(26.28 \%)$ \\
\hline Home feeding & $11(22 \%)$ & $10(18.52 \%)$ & $17(32.69 \%)$ & $49(31.41 \%)$ \\
\hline Supplement feeding & $8(16 \%)$ & $24(44.44 \%)$ & $29(55.77 \%)$ & $97(62.18 \%)$ \\
\hline Marketing duringshok & $23(46 \%)$ & $45(83.33 \%)$ & $47(90.38 \%)$ & $138(88.46 \%)$ \\
\hline Health care & $44(88 \%)$ & $47(87.04 \%)$ & $26(50 \%)$ & $71(45.51 \%)$ \\
\hline Cross breed & $16(32 \%)$ & $29(53.70 \%)$ & $22(42.31 \%)$ & $55(35.26 \%)$ \\
\hline Irrigation for pasture & $11(22 \%)$ & $22(40.74 \%)$ & $16(30.77 \%)$ & $76(48.71 \%)$ \\
\hline Shade for dry season & $17(34 \%)$ & $43(79.62 \%)$ & $24(46.15 \%)$ & $71(45.51 \%)$ \\
\hline Feeding watering trough & $15(30 \%)$ & $32(59.26 \%)$ & & \\
\hline
\end{tabular}

Note: Field survey, 2018.

\section{Adaptation Practices to Climate Change by Livestock Producers'}

Figure 13, indicates whether farmers used the adaptation practices on their livestock to adapt climate change or not based on sex. Due to this among the female house hold head 33(89.20\%) respondents and male105 (88.23\%) respondents were said that; they used adaptation practices on their livestock to adopt climate change and the remained percent 14 (11.76\%) males and 4(10.81\%) females were said not used adaptation practices on their livestock to adopt climate change. As shown in Figure 14, indicated that; farmers' perception on adaptation to climate change based on age categories. Due to this; among the age categories between 36-45 old were perceived on climate adaptation than other age categories. Farmers said; whether practiced or not to adapt climate change based on agro ecology. Due to this; the perception of respondents on climate adaptation was kept on different agro ecology categories as following respectively. Such as 51(94.44\%) midland, 49 (94.23\%) lowland and 38 (76\%) highlands Figure 15. This means most of the midland respondents said that; they used adaptation practices on their livestock to adapt climate change more than lowland and highland respondents. Education has an important effect on the choice of adaptation strategies to climate change. Because literates' individual peoples are expected to perceive about climate change and thus chooses compatible adaptation strategies.

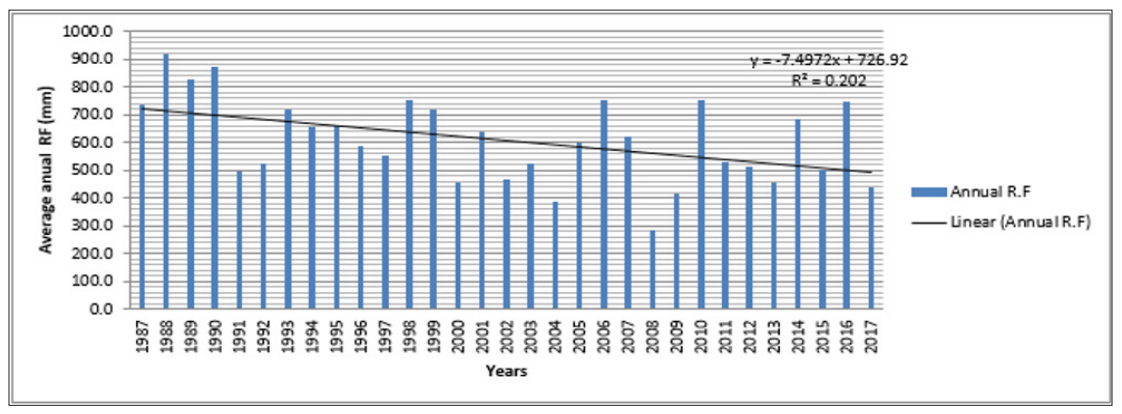

Figure 13: Trend of annual rainfall in study area (1987-2017).

Tigray metrological data of the study area 2018.

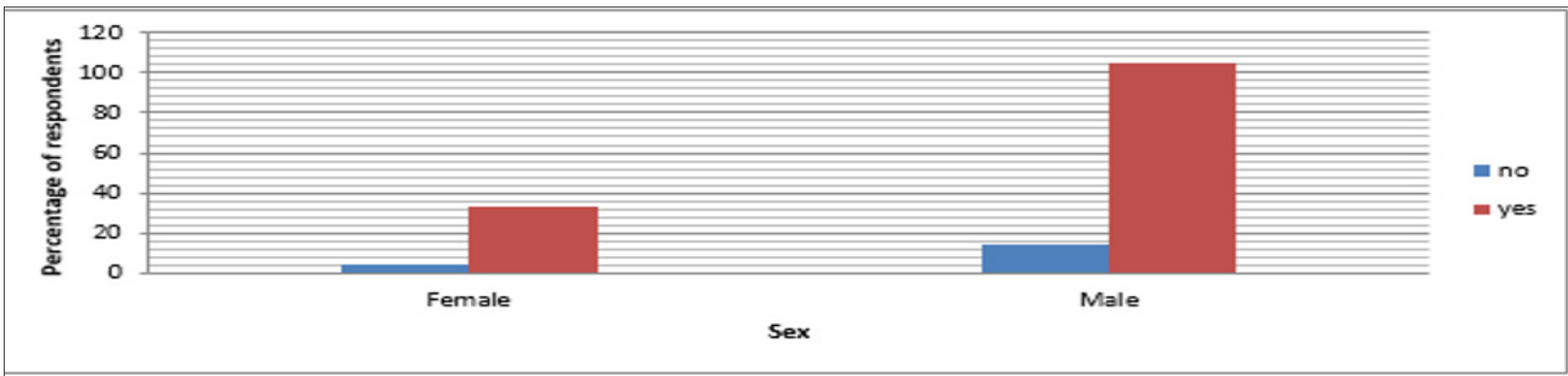

Figure 14: Livestock farmers' adaptation practices to climate change sex basis. 


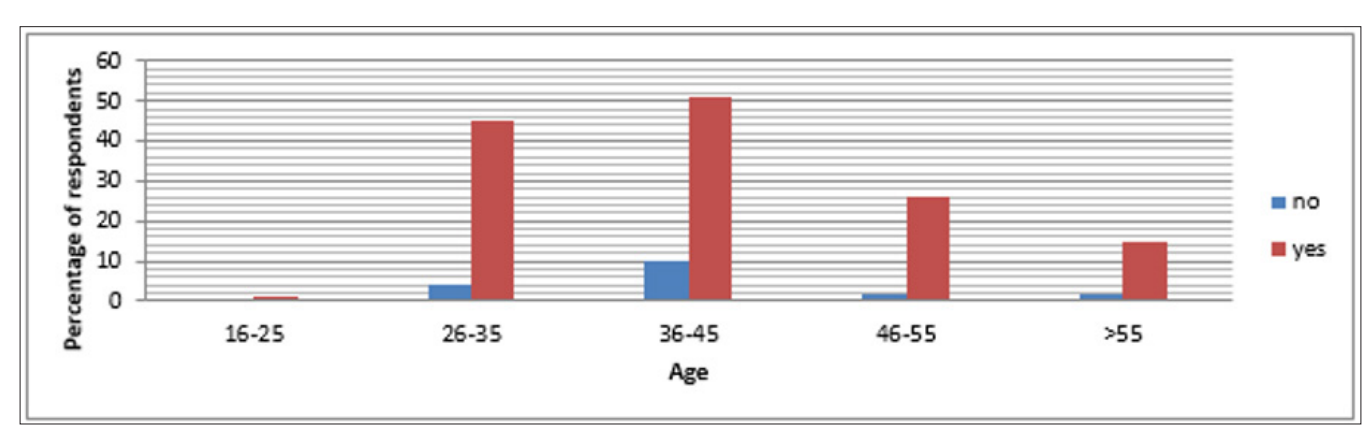

Figure 15: Farmers perception on climate adaptation age basis.

As shown in Figure 16, during the questioner survey out of 156 respondents $72(46.14 \%)$ of farmers were illiterates and 84 $(53.86 \%)$ respondents were literates. Due to this, out of 72 illiterates' respondents 60 (83.30\%) were used different adaptation practices on their livestock to adapt climate change. While12 (16.7\%) of non-illiterate's respondents were not used adaptation practices on their livestock to adapt the adverse of climate change. While out of the 84 literates' respondents $78(92.86 \%)$ were used adaptation practices on their livestock to adapt climate change. whereas the rest $6(7.14(\%)$ of literate respondents were not used adaptation practices on their livestock to adopt climate change. Then in this study indicated that literate respondents said had more used adaptation practices on their livestock to adapt climate change than non-educated respondents. So there is a significant different between literate and non-literate farmers on climate change adaptation ( $\mathrm{p}<.016)$ Figure 17 described that, most of the farmers' responded had practiced adaptation methods on their livestock to adapt climate change based on family size. Especially, among the numbers of family size which have between 1-5 family sizes more perceived and used adaptation practices on their livestock to adapt climate change than the other family size categories.

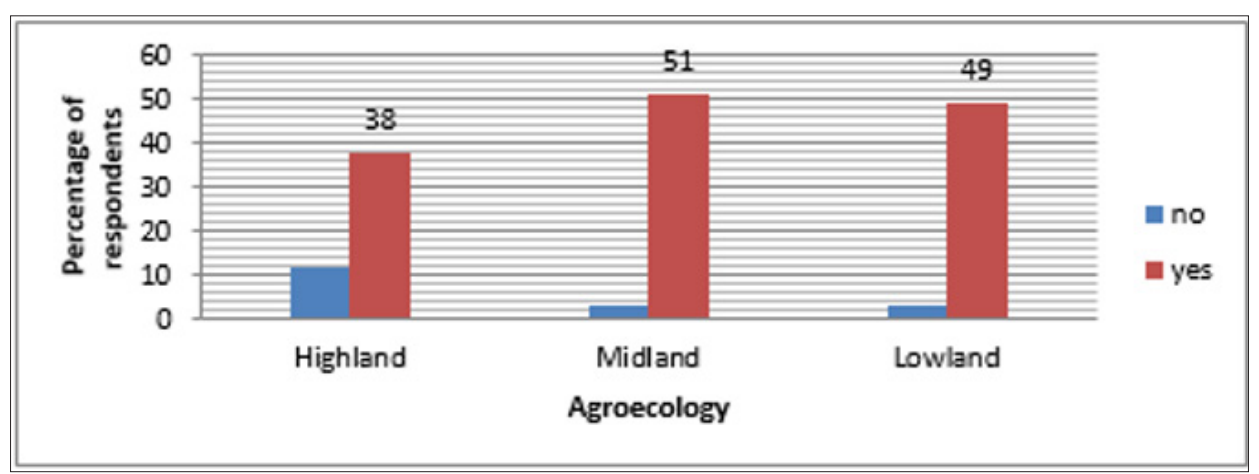

Figure 16: Farmers adaptation on climate change agro ecology basis.

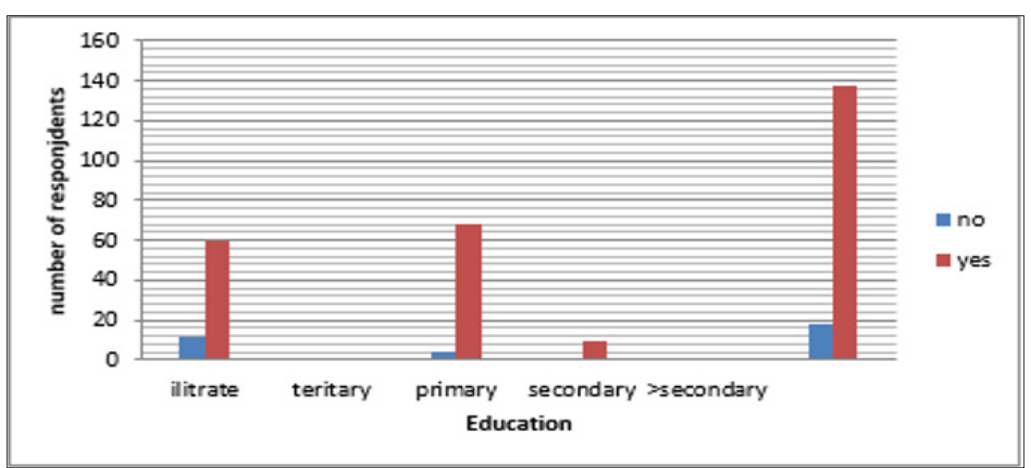

Figure 17: Education level relation to adaptation on climate change.

However, in this study indicates that, there is no a statistically significant different among the different family size on climate adaptation practices on their livestock. Figure 18 indicated that; livestock farmers' adaptation practices relation to farmers' experience. Due this; farmers who have $<10$ years' experience that describe more had been used adaptation practices on their livestock to adapt climate change than other farmers experience categories. This may be due to their educational level and the adequate assess of information on climate change. As shown in Figure 19, out of hundred and fiftysix respondents abut 147 (94.22\%) farmers 
'have own land, whereas the rest $9(5.8 \%)$ respondents have no own land. This indicates that, there is statistical different $(\mathrm{p}<.000)$ between the land owned farmers' and none land owned farmers. Particularly, as compared the three agro-ecological zones; the number of farm participant in the lowland agro ecological zone $52(100 \%)$ respondents have own land than the other two agro ecological zone.

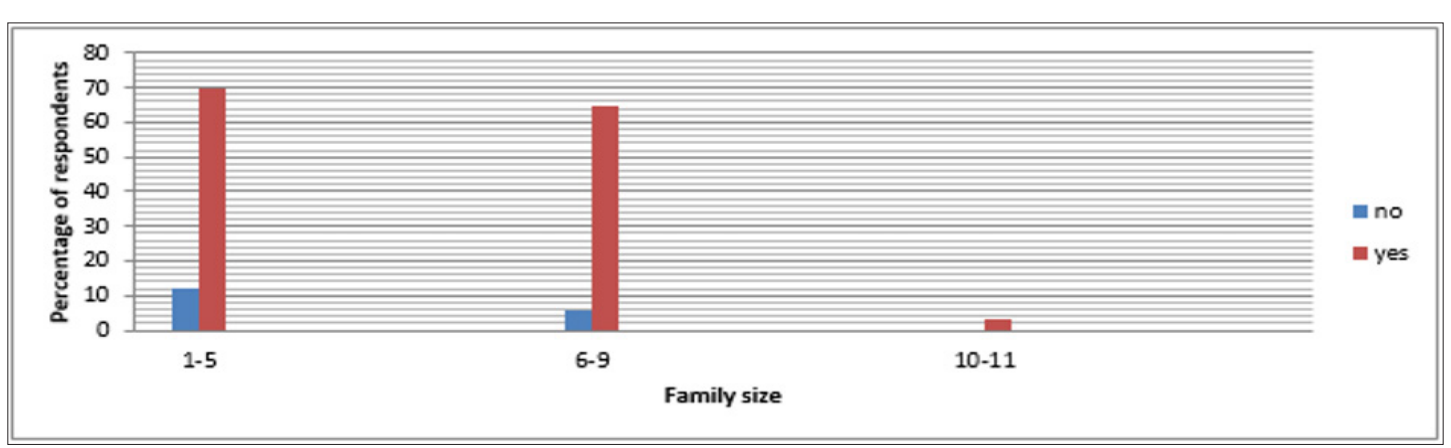

Figure 18: Farmers adaptation practices on livestock relation to family size.

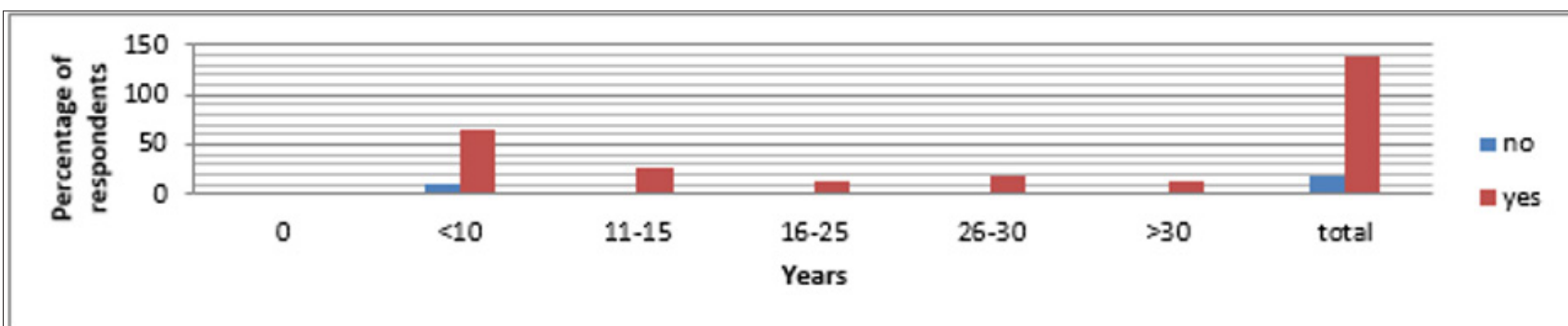

Figure 19: Farmers adaptation practices on livestock based on farmers' experience.

This descriptive statistical analysis also described that, compared between the female and male owned land and none own land. Due to this, out of 119 male respondents 113(94.96\%, and out of 37 female respondents'34(91.89\%) have own land respectively, whereas the rest $6(5.04 \%)$ male and $3(8.1 \%)$ female have no own lands. this indicates that male respondents have own lands than female respondents. However, there is not significant different between lands owned male and female respondents. As shown in Figure 20. Indicate that, out of 156 respondents 147(94.22\%) have own land and about 138 (88.46\%) respondents have been used different adaptation practices on their livestock to adopt climate change. But the rest 18 (11.54\%) respondents have not used adaptation practices on their livestock to adopt the adverse of climate change. So, this indicates the owned land farmers more participated or used adaptation practices on their livestock to adapt climate change than non-owned land farmers. However, the adaptation practices based on land size was there is no significant different.

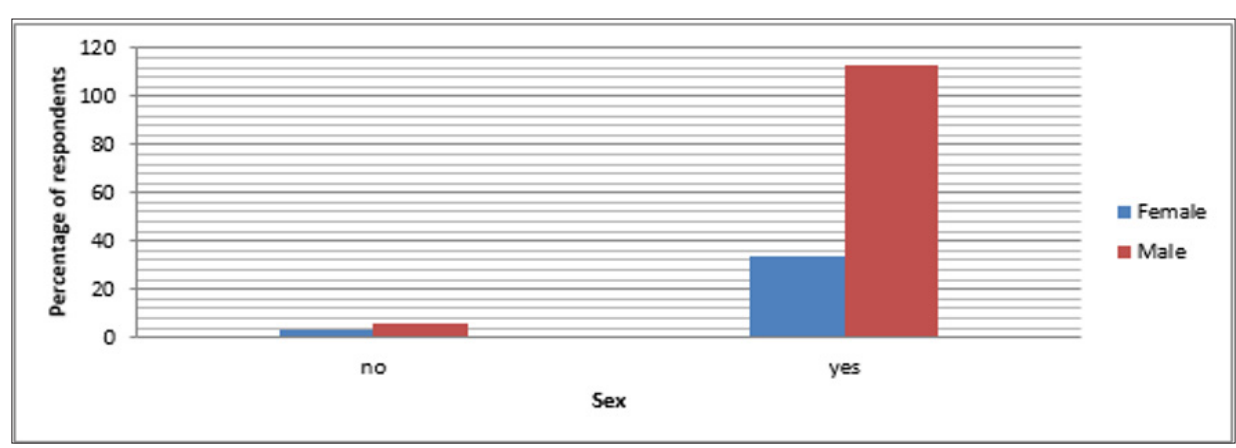

Figure 20: Farmers whether have own land or not based on sex.

The farmers responded or said that, climate change is can effect on livestock production. Especially the midland respondents more perceived than the other agro ecology categories. As shown in the above Table 8 . The most common farmers' used different adaptation practices on their livestock to adopt climate change on the three agro ecological setting. These includes; health care $138(88.46 \%)$, clean of shade $128(82.05 \%)$, provision of shade 120 (76.92\%), Marketing during shock 97(62.18\%), Shade for day and dry season76 (48.71\%), Feeding\& watering trough and cross bred $71(45.51 \%)$ respectively. However, when compared the farmers 
perception on climate change adaptation practices among three agro ecological setting; the midland respondents were familiar or used different adaptation practices on their livestock to adopt climate change than the other agro ecological setting (highland and lowland) in the study area.
Benefit of Climate Adaptation Practices on Livestock: Most of the respondents perceived or agreed that, the benefit of climate adaptation practices on livestock was very crucial and revealed that increase animal production (like milk, meat, eggs) and increase animal reproductivity and decrease animal pest and disease.

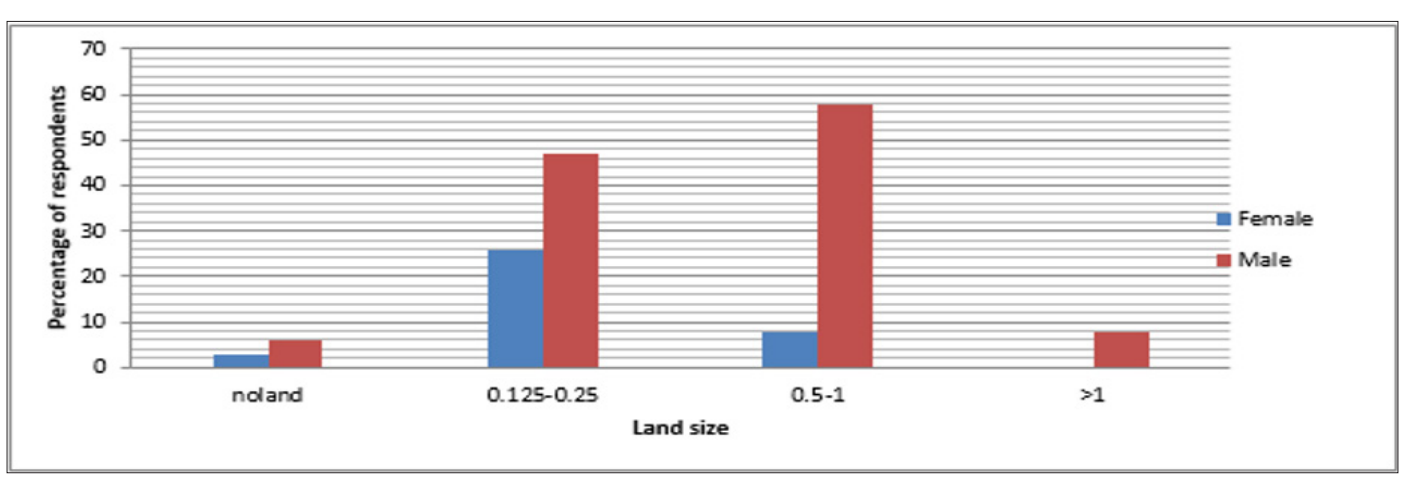

Figure 21: Farmers adaptation practices on livestock based on land size.

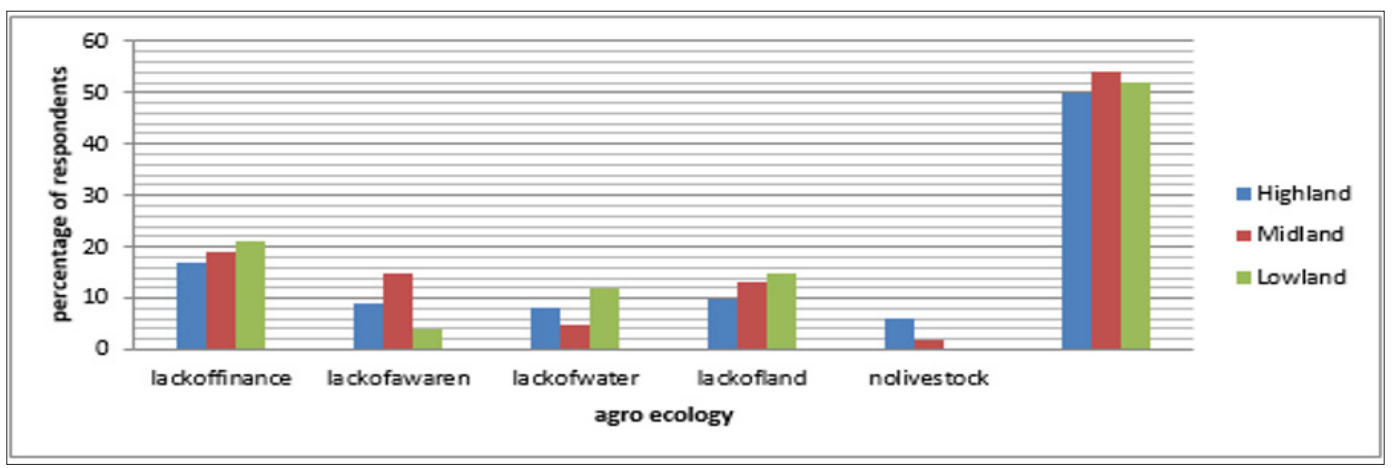

Figure 22: Barriers to climate change adaptation practices based on agro ecology.

\section{Barriers to Climate Change Adaptation Practices by Livestock Farmers}

The major constrains or barriers to adapt climate change by livestock farmers are listed in Figures 21 \& 22, such as lack of finance, lack of awareness, lack of water and lack of land. As citied by Temesgen et al. the analysis of barriers to adaptation practice to climate change in the Nile basin of Ethiopia indicates that, there are five major constraints to adaptation. These are lack of information, lack of money, shortage of labor, shortage of land, and poor potential for irrigation. Then the barriers to adaptation practices on climate change by livestock farmers' almost similar Tumescent previous study with my study.

\section{Discussion}

Findings from the three agro ecological area that more than $96.15 \%$ of local farmers were able to perceive the adverse effects of climate change. They apparently noticed that climate change reduced the amount of rainfall, which evidently exhibited in terms of occurrence of frequent drought with its immediate consequences on loss of their livestock production. The responding the negative effects of climate change, producers of ruminants' livestock continued to pursue multiple adaptation methods. Field -based assessments on indicators of multiple adaptation choices were conducted and the estimated results indicated that nearly $97(62.18 \%)$ of the farmers were found to use marketing. During drought periods, farmers used to sell their livestock because of fear of lack of natural grazing and animal feed and animal pest (diseases).

\section{Conclusion and Recommendation}

Livestock can make a large contribution to climate-friendly supply systems. The sector offers substantial potential for climate change mitigation and adaptation. Mitigation options are available along the entire supply chain and are mostly associated with feed production, enteric fermentation and manure management. Livestock's role in adaptation practices relates to organic matter and nutrient management (soil restoration) and income diversification. Livestock also makes a key contribution to food security, especially in marginal lands where it represents a unique source of energy, protein and micronutrients. The contribution of the livestock sector to food security could be strengthened, particularly in areas where current levels of consumption of livestock products are low. One can see that in this study, the perceived climate change and variability by farmers are not in line with the gauged meteorological data 
results. Majority of farmers 122 (78.2\%) in the study area perceived an increase in temperature with some variability among the agro ecologies and among age groups.

On the other hand the perceived trend on rain fall indicates that most of the farmer'110 (70.5\%) perceived the decreasing trend. The world meteorological organization recommended at least 30 years minimum data in order to understand the trends of a given area's climate variability and change. So it is better to rely on perceived climatic trend results than the meteorological data results. The adaptation strategy by farmers is also in line with their perceived climate changes of the area rather than that of the positive meteorological results. The farmers' adaptation practices on their livestock to adapt to the changing climate on the three agro ecological setting; are Health care, provision of Shade, Marketing during shock, Shade for dry season, Feeding\& watering trough and cross bred. These practices are among climate change adaptation strategies devised by IPCC therefore farmers are very much aware of their area's climate trend as their response strategy indicated. So from this one can see that the climate change of the area are negatively affecting the study area's farming community as it is already seen and indicated by the survey results and the discussants of key informants and focus groups.

Based on this the following are recommended:

a) It is necessary to ensure inter-sectoral coordination and cooperation.

b) Considerable investment in:

i. Filling data and knowledge gaps and research.

ii. Development of technologies.

iii. Conservation and production of suitable varieties and breeds.

c) Strengthened institutional capacity to improve dissemination of modern adaptation strategies over large areas and numbers of farmers.

d) Institutional and financial support for smallholders to make the transition to better livestock management that is in climate smart principle manner.

e) The use of weather information to assist rural communities in managing the risks associated with rainfall for livestock management that needs to be addressed.

f) Agro forestry is an integrated approach to the production of trees and non-tree crops or animals on the same piece of land.

g) Agro forestry is important both for climate change mitigation (carbon sequestration, improved feed and consequently reduced enteric methane) and for adaptation in that it improves the resilience of agricultural production to climate variability by using trees to intensify and diversify production and buffer farming systems against hazards. Shade trees reduce heat stress on animals and help increase productivity. Trees also improve the supply and quality of forage, which can help reduce overgrazing and land degradation.

h) Increased access to agricultural support services, which improves the availability and the quality of relevant climate information will further enhance awareness of climate change within of the rural community and result in better management of climate-induced risks in these vulnerable livestock production systems.

\section{References}

1. Stern N (2006) What is the Economics of Climate Change? World economics 7(2): 1-10.

2. Watson B (2010) Climate change: An environmental development and security issue.

3. DC Deressa TT, Hassan RM, Ringler C, Alemu T, Yusuf M (2009) Determinants of farmer's choice of adaptation methods to climate change in the Nile Basin of Ethiopia. Global Environmental Change 19(2): 248-255.

4. Thornton PK, Kruska RL, Henninger N, Kristjanson PM, Reid RS, et al. (2002) Mapping poverty and livestock in the developing world. International Livestock Research Institute publishers, Nairobi, Kenya.

5. Funk C, Rowland J, Eilerts G, Kebebe E, Biru N, et al. (2012) A climate trend analysis of Ethiopia. Climate change adaptation series. US Geological Survey. Famine Early Warning Systems Network-Informing (FEWSNET): 6.

6. Abebe T, Addis Ababa (2007) National Meteorological Agency (NMA). Climate change national adaptation program of action of Ethiopia. In: Abebe T, Addis Ababa (Eds.), Ethiopia.

7. Alebachew A, Woldeamlak B (2011) A Climate Change Country Assessment Report for Ethiopia. Submitted to Forum for Environment. Epsilon International R\&D. Addis Ababa, Ethiopia.

8. Deressa T, Hassan RM, Alemu T, Yusuf M, Ringler C (2008) Analyzing the determinants of farmers choice of adaptation methods and perceptions of climate change in the Nile Basin of Ethiopia. In: International food policy research institute (IFPRI) Washington DC, USA.

9. Easter ling W, Apps M (2005) Assessing the consequences of climate change for food and forest resources: a view from the IPCC. In Increasing Climate Variability and Change Springer Netherlands 70(1-2): 165-189.

10. FDRE (2011) Ethiopia's climate-resilient green economy green economy strategy. Addis Ababa, Ethiopia Google, pp. 65-189.

11. Mengestu DK (2011) Farmers perception and knowledge of climate change and their coping strategies to the related hazards: case study From Adiha, Central Tigray, Ethiopia. J Agric Sci 2(2): 138-145.

12. Gebreegziabher Z, Stage J, Kekkonen A (2011) Climate change and the Ethiopian economy: a computable general equilibrium analysis. Resources for the Future, Washington, USA

13. Deressa TT, Hassan RM, Ringler C (2011) Perception and adaptation to climate change by farmers in the Nile Basin of Ethiopia. Journal of Agricultural Science 149: 23-31.

14. Delgado CL (2005) Rising demand for meat and milk in developing countries: implications for grasslands based livestock production. In Mc Gill way, DA (Eds.) Grassland: a global resource, Wageningen Academic Publishers, Wageningen the Netherlands, pp. 29-39.

15. FAO (2010) Greenhouse gas emissions from the dairy sector. A life cycle assessment. A report prepared by Food and Agriculture Organization of the United Nations animal production and health division, FAO, Rome.

16. FAO (2010) Climate change adaptation and mitigation: New initiatives and update on Agriculture, Forestry and Fisheries. Proceedings: 
Thirtieth FAO Regional Conference for the Near East: Khartoum the Republic of the Sudan.

17. FAO (2009) Preparation of national strategies and action plans for animal genetic resources. Animal Production and Health Guidelines, No. 2. Food and Agriculture Organization of the United Nations, Rome, Italy.

18. Central Statistical Authority (2011) Agricultural sample survey 20102011. Report on livestock and livestock characteristics Addis Ababa, Ethiopia.

19. Hoffmann I (2010) Climate change and the characterization, breeding and conservation of animal genetic resources. Animal Genetics 41(Suppl 1): 32-46.

20. Thornton PK, Gerber PJ (2010) Climate change and the growth of the livestock sector in developing countries. Mitigation Adaptation Strategy of Glob Change 15(2): 169-184.

21. Solomon D (2001) Cattle population dynamics in the southern Ethiopian rangelands. Research brief -01-02. The GL-CRSP Pastoral Risk Management Project (PARIMA). Utah State University, Logan, Utah, USA.

22. Kgosikoma OE (2006) Effects of climate variability on livestock population dynamics and community drought management in Kgalagadi, Botswana. MSc thesis Norwegian University of Life Sciences, Norway, p. 57.

23. Abdeta A (2011) Effects of drought on cattle herd dynamics and its implication on local livelihood systems in Borana, Ethiopia. Food Security Center (FSC) Brief p. 1-6.

24. OSeni S, Bebe O (2010) Climate change, genetics of adaptation and livestock production in low-input systems. In: 2nd international conference: climate, sustainability and development in semi-arid regions, Fortaleza Ceará, Brazil Google.

25. Sahoo A, Kumar D, Naqvi SMK (2013) Climate resilient small ruminant production. In Sahoo A, Kumar D, Naqvi SMK (Eds.) National Initiative on Climate Resilient Agriculture (NICRA) Izatnagar, India: pp. 1-106.

26. Taruvinga A, Muchenje V, Mushunje A (2013) Climate change impacts and adaptations on small-scale livestock production. International Journal of Development and Sustainability 2(2): 664-685.

27. Al Haidary AA (2004) Physiological responses of Niamey sheep to heat stress challenge under semi-arid environments.

28. Sevi A, Casamassima D, Pulina G, Pazzona A (2009) Factors of welfare reduction in dairy sheep and goats. Italian Journal of Animal Science 8(sup1): 81-101.

29. Alam MM, Hashem MA, Rahman MM, Hossain MM, Haque MR, et al. (2011) Effect of heat stress on behavior, physiological and blood parameters of goat 22(1-2): 37-45.

30. Henry B, Charmley E, Eckard R, Gaughan JB, Hegarty R (2012) Livestock production in a changing climate: adaptation and mitigation research in Australia. Crop and Pasture Science 63(3): 191-202.

31. Singh SK, Meena HR, Kolekar DV, Singh YP (2012) Climate change impacts on livestock and adaptation strategies to sustain livestock production. J Vet Adv 2(7): 407-412.

32. Di Falco S, Yusuf M, Kohlin G, Ringler C (2012) Estimating the impact of climate changes on agriculture in low-income countries: Household level evidence from the Nile Basin, Ethiopia. Environmental and Resource Economics 52(4): 457-478.

33. Di Falco, S Yusuf M, Kohlin G (2009) On adaptation to climate change and food production in the Nile basin, Ethiopia. Unpublished paper Ethiopia.

34. Panin A (2000) A comparative economic analysis of smallholder cattle and small ruminant production systems in Botswana. Tropical Animal Health and Production 32(3): 189-196.

35. Legesse G, Abebe G, Siegmund Schultze M, Zarate AV (2008) Small ruminant production in two mixed-farming systems of southern
Ethiopia: status and prospects for improvement. Experimental Agriculture 44(3): 399-412.

36. Abraham M, Birtukan Atinkut (2016) Determinants of farmers choice of adaptation to climate variability in Deraworeda, south Gondar zone, Ethiopia.

37. Mandleni B, Anim FDK (2011) Perceptions of cattle and sheep farmers on climate change and adaptation in the Eastern Cape province of south Africa. J Hum Ecol 34(2): 107-112.

38. Kemausuor F, Dwamena E, Bart Plange A, Kyei Baffour N (2011) Farmers perception of climate change in the Ejura Sekyedumase district of Ghana. J Agric Biol Sci 6(10): 26-37.

39. Apata TG (2011) Factors influencing the perception and choice of adaptation measures to climate change among farmers in Nigeria: evidence from farm households in Southwest Nigeria. Environ Econ 2(4): 74-83

40. IPCC International Panel on Climate Change (2007) "Climate Change 2007: the physical science basis. Summary for policy makers. Assessment Report" Cambridge University Press, Cambridge, UK.

41. International Fund for Agricultural Development (2009) Livestock and climate change. Livestock thematic papers.

42. IFAD (2009) Comprehensive Report on IFAD's Response to Climate Change through Support to Adaptation and Related Actions.

43. International Fund for Agricultural Development (IFAD) (2010) Livestock and climate change. IFAD publishers, Rome.

44. IPCC (Intergovernmental Panel on Climate Change) (2001) Climate Change: The Scientific Basis.

45. Intergovernmental Panel on Climate Change IPCC (2007) Impacts, adaptations and vulnerability. Fourth Assessment Report. Cambridge University Press, Cambridge, UK.

46. IPCC (Intergovernmental Panel on Climate Change) (2013) Climate change 2013: The physical science basis.

47. Kurukulasuriya P, Mendelsohn R (2008) A Ricardian analysis of the impact of climate exchange on African cropland. African Journal of Agricultural and Resource Economics 2(1): 123.

48. Mc Dermott JJ, Kristjanson PM, Kruska RL, Reid RS, Robinson TP, et al. (2002) Effects of climate, human population and socio-economicchanges on tsetse-transmitted trypanosomiasis to 2050. World Class Parasites 1 : 25-38.

49. Meyer WB (1996) Human Impact on the Earth. In Meyer WB(Eds.) Cambridge: Cambridge University Press, UK.

50. Nisbet EG (1991) Leaving Eden: To Protect and Manage the Earth. In: Nisbet EG (Eds.), Cambridge University Press, Cambridge, United Kingdom.

51. Notenbaert A, Mude A, Van de Steeg J, Kinyangi J (2010) Options for adapting to climate change in livestock-dominated farming systems in the greater horn of Africa. Journal of Geography and Regional Planning 3(9): 234-239.

52.(2001) NMSA (National Meteorological Services Agency) Initial national communication of Ethiopia to the United Nations Framework Convention on Climate Change (UNFCCC), Addis Ababa, Ethiopia.

53. Sejian V, Gaughan JB, Raghavendra Bhatta, Naqvi SMK (2016) Impact of climate change on livestock productivity.

54. Seo SN, Mendelssohn R, Dinar A, Kurukulasuriya P (2009) Adapting to climate change musically: an analysis of African livestock management by agro-ecological zones. The BE Journal of Economic Analysis \& Policy $9(2)$

55. Seo SN, Mc Carl BA, Mendelssohn R (2010) From beef cattle to sheep under global warming? An analysis of adaptation by livestock species choice in South America. Ecological Economics 69(12): 2486-2494. 
56. Sidahmed A (2008) Livestock and climate change: Coping and risk management strategies for a sustainable future. In: Livestock and Global Climate Change Conference Proceeding, May, Tunisia.

57. (2004) UN/ISDR (Inter-Agency Secretariat of the International Strategy for Disaster Reduction) (2004) Living with Risk - A global review of disaster reduction initiatives.

58. (2008) United Nations, Climate change and disaster risk reduction.

59. (1992) UNFCCC United Nations Framework Convention on Climate Change 2006, Technologies for adaptation to climate change. United Nations Framework Convention on Climate Change, Germany.

60. Wackernagel M, Rees W (1996) Our Ecological Footprint: Reducing Human Impact on the Earth. New Society Publishers, Philadelphia.

61. Zhang YW, Hagerman AD, Mc Carl BA (2013) Influence of climate factors on spatial distribution of Texas cattle breeds. Climatic change 118(2): 183-195.

62. Anders Ekbom (2013) Ethiopia environment and climate change policy brief and International. Journal of Agriculture and Biology 2: 307-309.

63. Aydinalp C, Cresser MS (2008) The effects of global climate change on agriculture. American-Eurasian journal of agricultural and environmental science 3(5): 672-676.

64. Ban Ki Moon (2009) Climate change quotations.

65. Battaglini A, Barbeau G, Bindi M, Badeck FW (2009) European winegrowers' perceptions of climate change impact and options for adaptation. Regional Environmental Change 9(2): 61-73.

66. Batima P (2006) Climate change vulnerability and adaptation in the livestock sector of Mongolia. Assessments of impacts and adaptations to climate change. International START Secretariat, Washington DC, USA.

67. Cook J, Nuccitelli D, Green SA, Richardson M, Winkler B, et al. (2013) Quantifying the consensus on anthropogenic Global warming in the scientific literature. Environmental Research Letters 8(2): 024024.

68. FAO (Food and Agriculture Organization of the United Nations) (1997) Irrigation potential in Africa: A basin approach.

69. FAO (2008) Climate-related Tran boundary Pests and Diseases Including Relevant Aquatic Species. Technical background document from the expert consultation held on 25 to 27 February, FAO, Rome.

ISSN: 2574-1241

DOI: $10.26717 / B J S T R .2018 .11 .002166$

Guo Ruo. Biomed J Sci \& Tech Res

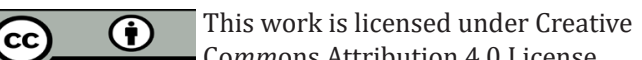

Submission Link: https://biomedres.us/submit-manuscript.php
70. Food and Agriculture Organization (FAO) (2008) Climate change for fisheries and aquaculture: Technical background document from the expert consultation held on7-9 April, Rome.

71. FAO (2010) Breeding strategies for sustainable management of animal genetic resources. Animal Production and Health Guidelines, No. 3. Food and Agriculture Organization of the United Nations, Rome, Italy.

72. Gill P, Chadwick B (2008) Analyzing and presenting qualitative data. British Dental Journal 204: 429-432.

73. Gill M, Smith P, Wilkinson JM (2010) Mitigating climate change: the role of domestic livestock. Animal 4 (3): 323-333.

74. Giridhar K, Samireddypalle A (2015) Impact of climate change on forage availability for livestock. Climate Change Impact on Livestock: Adaptation and Mitigation pp. 97-112.

75. Hoffman MT, Vogel C (2008) Climate change impacts on African rangelands. Rangelands 30(3): 12-17.

76. Hoffmann I (2008) Livestock genetic diversity and climate change adaptation. Livestock and Global Change Conference proceeding, Tunisia.

77. IPCC TAR (2001) Climate Change 2001: The Scientific Basis. IPCC. IPCC Third Assessment Report, Cambridge University Press vulnerability, Fourth Assessment Report, Cambridge University.

78. Intergovernmental Panel on Climate Change (IPCC) (2007) Impacts, adaptations and vulnerability. Fourth Assessment Report. Cambridge University Press, Cambridge, UK.

79. Kemausuor F, Dwamena E, Bart Plange A, Kyei Baffour N (2011) Farmers' perception of climate change in the Ejura-Sekyedumase district of Ghana. J Agric Biol Sci 6(10): 26-37.

80. Mannion A M (1997) Global environmental change: a natural and cultural environmental history. In: Mannion AM (Eds.), Harlow: Longman Press, New York, USA.

81. Thornton PK, Kruska RL, Henninger N, Kristjanson PM, Reid RS, et al. (2002) Mapping poverty and livestock in the developing world. International Livestock Research Institute publishers, Nairobi, Kenya.

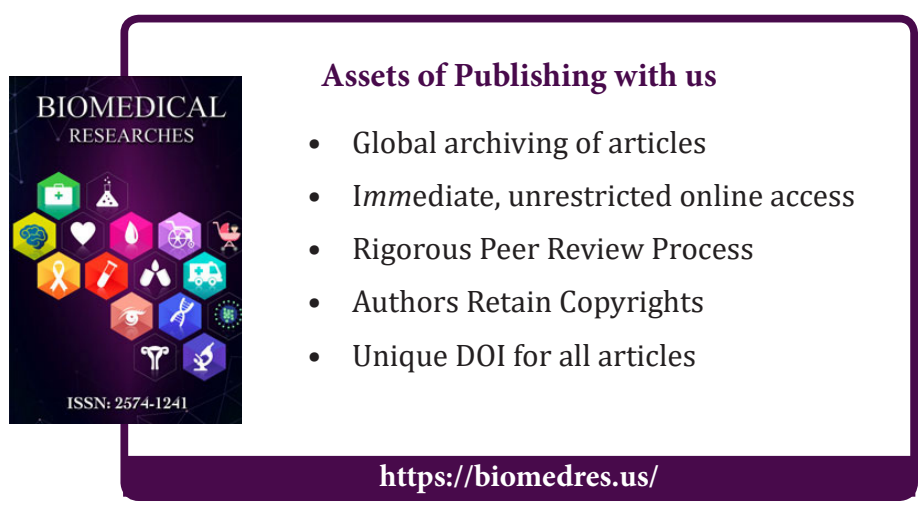

Cite this article: Guo R, Brhane W, Genet Y, Gebremedhin Y. Climate Change Adaptation Practices by Ruminant Livestock Producer of in Hintalo Wajerat District Tigray Regional State, Northern Ethiopia. Biomed J Sci \& Tech Res 11(5)-2018. BJSTR. MS.ID.002166. D0I: 10.26717/ 